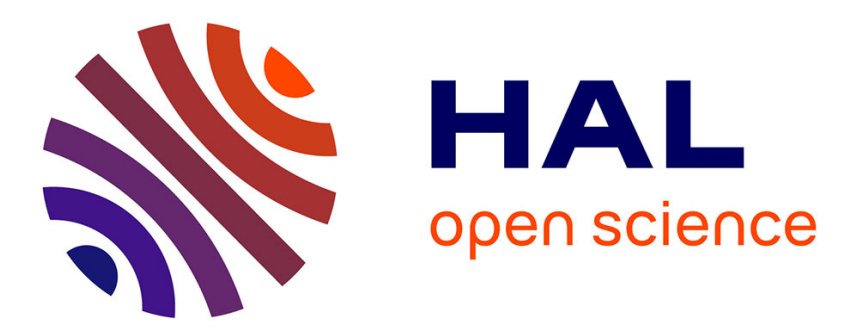

\title{
Palladium(ii) complexes with planar chiral ferrocenyl phosphane-(benz)imidazol-2-ylidene ligands
}

Pauline Loxq, Nathalie Debono, S. Gulcemal, Jean-Claude Daran, E. Manoury, Rinaldo Poli, B. Cetinkaya, A. Labande

\section{- To cite this version:}

Pauline Loxq, Nathalie Debono, S. Gulcemal, Jean-Claude Daran, E. Manoury, et al.. Palladium(ii) complexes with planar chiral ferrocenyl phosphane-(benz)imidazol-2-ylidene ligands. New Journal of Chemistry, 2014, 38 (1), pp.338-347. 10.1039/C3NJ00863K . hal-02023133

\section{HAL Id: hal-02023133 https://hal.science/hal-02023133}

Submitted on 3 Mar 2021

HAL is a multi-disciplinary open access archive for the deposit and dissemination of scientific research documents, whether they are published or not. The documents may come from teaching and research institutions in France or abroad, or from public or private research centers.
L'archive ouverte pluridisciplinaire HAL, est destinée au dépôt et à la diffusion de documents scientifiques de niveau recherche, publiés ou non, émanant des établissements d'enseignement et de recherche français ou étrangers, des laboratoires publics ou privés. 


\title{
Palladium(II) complexes with planar chiral ferrocenyl phosphane/(benz)imidazol-2-ylidene ligands
}

\author{
Pauline Loxq, ${ }^{a, b}$ Nathalie Debono, ${ }^{a, b}$ Süleyman Gülcemal, ${ }^{c}$ Jean-Claude Daran, ${ }^{a, b}$ Eric Manoury, ${ }^{a, b}$ \\ Rinaldo Poli, ${ }^{a, b, d}$ Bekir Çetinkaya, ${ }^{c}$ and Agnès Labande*a,b
}

\author{
5 Received (in $X X X, X X X) X$ th $X X X X X X X X X 20 X X$, Accepted $X$ th $X X X X X X X X X 20 X X$ \\ DOI: 10.1039/b000000x
}

\begin{abstract}
We describe here the first examples of planar chiral ferrocenyl phosphane/benzimidazol-2-ylidene ligands and their coordination chemistry with palladium(II). All ligand precursors, namely enantiopure ferrocenyl phosphane/(benz)imidazolium salts, and all enantiopure palladium complexes have been fully characterised ${ }^{10}$ by ${ }^{1} \mathrm{H},{ }^{31} \mathrm{P}$ and ${ }^{13} \mathrm{C}$ NMR, mass spectrometry and X-ray diffraction methods for seven examples. The potential of these very bulky bidentate ligands in catalysis was evaluated and compared to their imidazol2-ylidene analogues. The influence of sterics was shown to be non-negligible as the bulkiest ligand gave the lowest activities in the asymmetric Suzuki-Miyaura reaction.
\end{abstract}

\section{Introduction}

15 The synthesis and coordination chemistry of functionalised $N$ heterocyclic carbene (NHC) ligands and their applications in catalysis has attracted the attention of several groups, ${ }^{1-3}$ including ours. $^{4-7}$ These strong $\sigma$-donor ligands proved very efficient in catalysis, even surpassing phosphanes in many cases. ${ }^{8}$ One 20 advantage of using N-heterocyclic carbenes is the high stability conferred to the metal complexes, thus avoiding the use of excess ligand or catalyst deactivation. Fine tuning the stereoelectronic properties of the $\mathrm{N}$-heterocyclic carbene may allow us finding useful trends in the search of the best catalyst, particularly in terms 25 of enantioselectivity. Recently, we described the synthesis of 1,1'disubstituted ferrocenyl phosphane/benzimidazol-2-ylidene ligands for applications in rhodium-catalysed hydrosilylation of carbonyl groups. It was shown in this case that the replacement of the imidazol-2-ylidene moiety by the more bulky, electron-rich 30 benzimidazol-2-ylidene bearing two methyl groups on the aromatic ring enhanced the catalytic activity dramatically. ${ }^{6}$

It is now commonly admitted that strongly electron-donating, bulky ligands favour oxidative addition on palladium and help stabilise the intermediate species in $\mathrm{C}-\mathrm{C}$ coupling reactions such 35 as for instance the Suzuki-Miyaura reaction. ${ }^{9-11}$ Furthermore, we have recently turned our attention to the asymmetric version of this reaction, obtaining encouraging results with the use of palladium complexes containing enantiomerically pure phosphane/imidazol2-ylidene ligands (Figure 1). ${ }^{7}$ We therefore turned our efforts 40 towards the synthesis of palladium complexes containing novel chiral 1,2-disubstituted ferrocenyl phosphane/(benz)imidazol-2ylidene ligands in enantiomerically pure form and describe here their synthesis. Their catalytic properties in the asymmetric Suzuki-Miyaura reaction ${ }^{11-15}$ have been evaluated and compared to 45 those of the above mentioned phosphane/imidazol-2-ylidene complexes. $^{7}$ Finally, the activity of a phosphane/imidazol-2- ylidene ligand in the asymmetric 1,2-addition of phenylboronic acid to 4-nitrobenzaldehyde has been evaluated. ${ }^{16-19}$

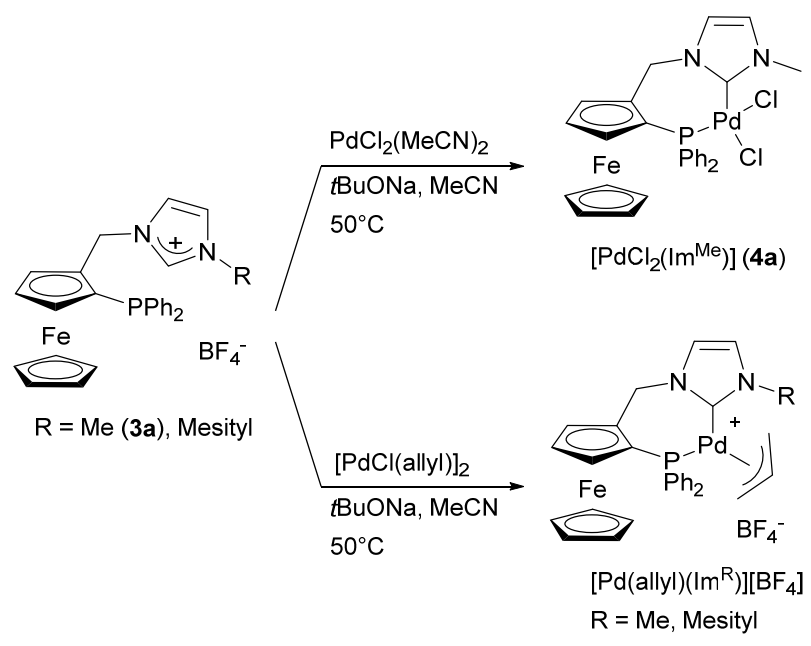

50 Scheme 1 Palladium(II) complexes described in our previous work. ${ }^{7}$

\section{Results and Discussion \\ Synthesis of (benz)imidazolium salts}

With the intention of varying the stereoelectronic properties of the ferrocenyl phosphane-NHC ligands in a rational way, we decided $5 s$ to focus on the NHC moiety without changing the diphenylphosphano group. The $\sigma$-donating properties of benzimidazol-2-ylidene ligands are situated between those of unsaturated imidazol-2-ylidenes and of saturated imidazolin-2ylidenes, which has been demonstrated in several examples of ${ }_{60}$ catalytic applications. ${ }^{20,21}$ Apart from the electronic properties, their structure should bring more bulkiness to the bifunctional ligands. In order to probe the effect of bulky substituents on both 
activity and enantioselectivity, we have also changed the nature of the $N$-substituent.

The synthesis of the phosphane/imidazolium salts with $\mathrm{R}=\mathrm{Me}$ (3a) has already been described, both in racemic ${ }^{5}$ and 5 enantiomerically pure form. ${ }^{7}$ The synthesis of other racemic and enantiomerically pure imidazolium and benzimidazolium salts was carried out following these established protocols. ${ }^{5}$ Racemic alcohol rac-1 was used mainly to develop and optimise the synthesis of various salts and palladium complexes, but only 10 enantiopure $(S)$-palladium complexes were used in catalytic reactions since we expected them to exhibit similar levels of activity compared to the previously described neutral palladium complex $\left[\mathrm{PdCl}_{2}\left(\mathrm{Im}^{\mathrm{Me}}\right)\right]$ (Scheme 1). ${ }^{7}$ Imidazolium salt $2 \mathbf{b}$ was obtained in moderate yield from ferrocenyl alcohol 1 and $N$ 15 [(2,4,6-trimethylphenyl)methyl] imidazole (Scheme 2).

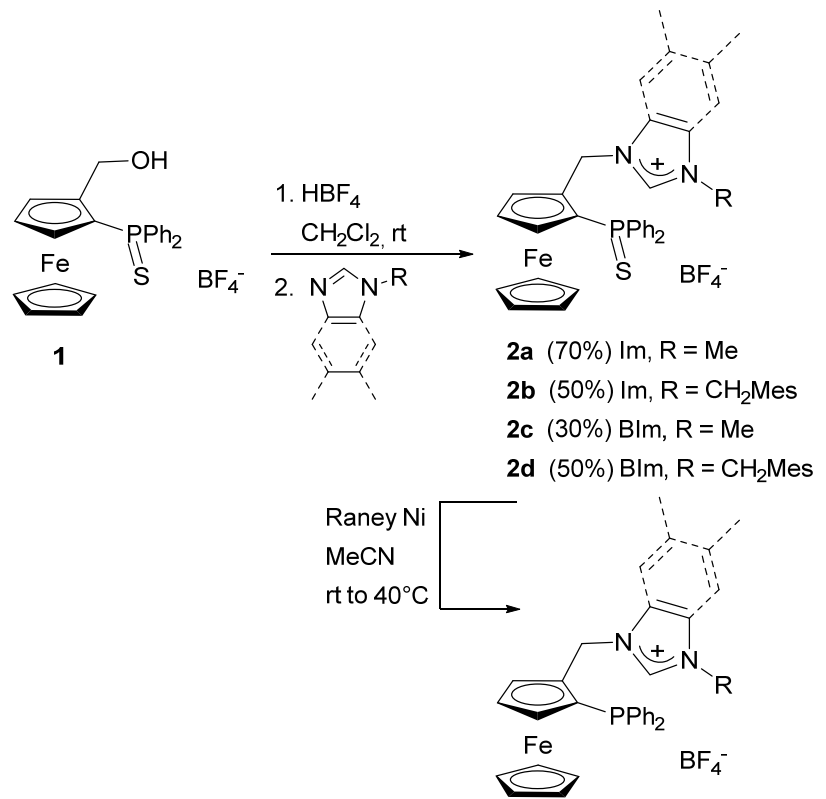

$$
\begin{aligned}
& \text { 3a }(95 \%) \mathrm{Im}, \mathrm{R}=\mathrm{Me} \\
& \text { 3b }(88 \%) \mathrm{Im}, \mathrm{R}=\mathrm{CH}_{2} \mathrm{Mes} \\
& \text { 3c }(90 \%) \mathrm{BIm}, \mathrm{R}=\mathrm{Me} \\
& \text { 3d }(82 \%) \mathrm{BIm}, \mathrm{R}=\mathrm{CH}_{2} \mathrm{Mes}
\end{aligned}
$$

Scheme 2 Synthesis of phosphane-(benz)imidazolium salts.

The synthesis of benzimidazolium salts $\mathbf{2 c}$,d, however, proved more difficult. Benzimidazoles are poorer nucleophiles compared

20 to imidazoles, thus giving greater amounts of side products and lower yields of benzimidazolium salts. Their purification was also less straightforward: the excess of $\mathrm{N}$-substituted benzimidazoles that are not consumed during the reaction cannot be removed with aqueous acidic washings due to their lower hydrophilicity and have 25 a tendency to trail on silica when the same eluting conditions as for the imidazolium salts are applied. Eventually, their purification was successful by eluting the $N$-substituted benzimidazole excess with pure diethyl ether and then the benzimidazolium salts with a DCM/acetone mixture on a silicagel chromatography column. The

${ }_{30}{ }^{1} \mathrm{H}$ NMR spectra of (benz)imidazolium salts $2 \mathbf{b}$-d show the expected signal above $\delta 8.5$, characteristic of the acidic $\mathrm{C} 2$ proton. $\mathrm{AB}$ systems were observed for the diastereotopic protons of the methylene bridge situated between the ferrocenyl and (benz)imidazolyl moieties for all salts, as well as for protons of the 35 methylene bridge linking the (benz)imidazolyl and mesityl groups (salts $\mathbf{2 b}$ and 2d), which is consistent with the introduction of planar chirality at ferrocene and with the generation of rather rigid structures due to steric crowding.
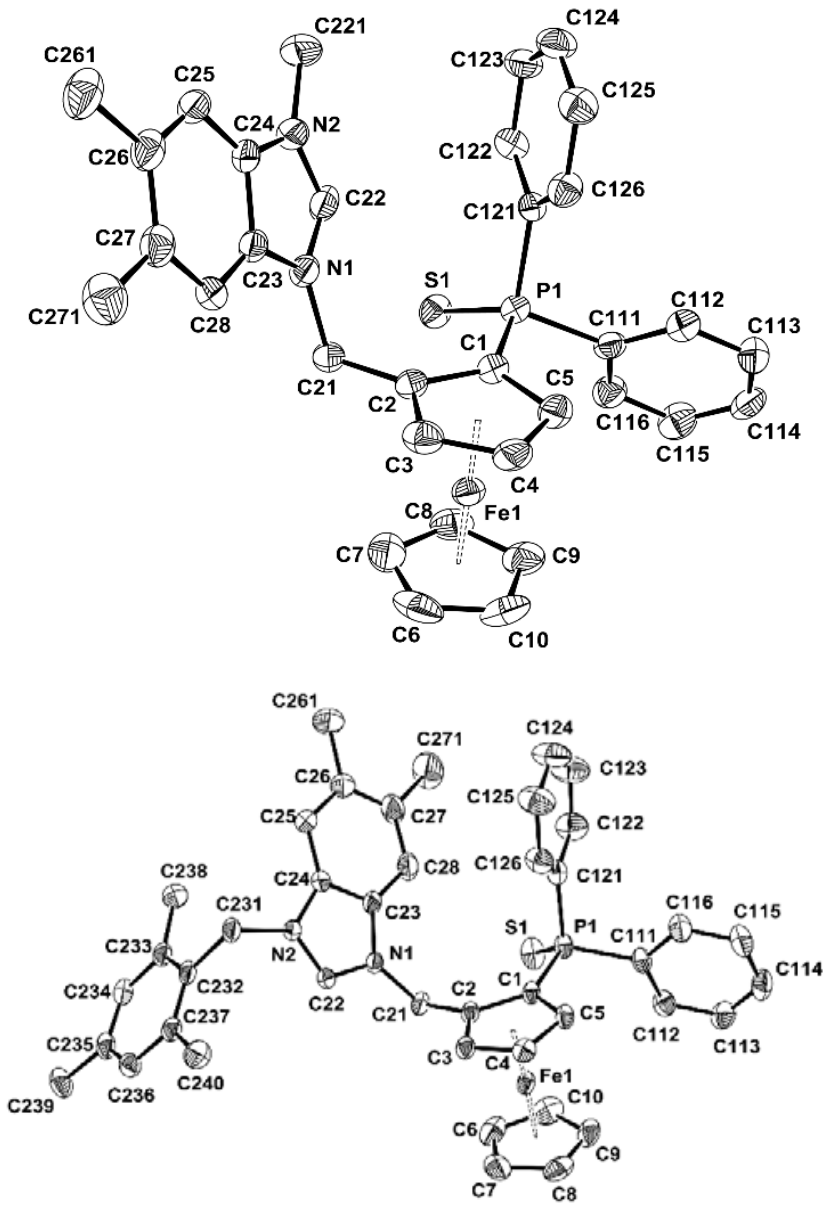

Fig. 1 ORTEP representations of benzimidazolium salts $\mathrm{rac}-2 \mathrm{c}$ (top) and rac-2d (bottom). Ellipsoids are shown at the 50\% level. All hydrogens are omitted for clarity. Selected bonds $(\AA)$, rac-2c: $\mathrm{C}(23)-\mathrm{C}(24)=1.388(8)$; rac-2d: $\mathrm{C}(23)-\mathrm{C}(24)=1.390(3)$.

45 The structure of the intermediates $2 \mathbf{c}$ and $2 \mathbf{d}$ (Figure 1) was confirmed by X-ray diffraction methods. The structures of the two salts as well as the one of $\mathbf{2 a} \$, 7$ are very close: the only notable structural difference resides in the length of the $\mathrm{C}-\mathrm{C}$ bond in the imidazolium motif, which is significantly shorter in the 50 imidazolium salt $(\mathrm{C}(7)-\mathrm{C}(8)=1.344(4) \AA)$ than in the benzimidazolium salts. This has already been observed in similar structures and indicates delocalisation of the $\mathrm{C}-\mathrm{C}$ bond $\pi$-electron density over the fused benzene ring. ${ }^{6}$

The imidazolium and benzimidazolium salts exhibited different 55 reactivity during the diphenylthiophosphano group deprotection by Raney nickel. Indeed, whereas the desulfurisation of the thiophosphane/imidazolium salt $\mathbf{2} \mathbf{b}$ to give $\mathbf{3 b}$ went to completion at room temperature in $16 \mathrm{~h}$, longer reaction times and moderate heating $\left(40^{\circ} \mathrm{C}\right)$ were necessary to achieve complete desulfurization ${ }_{60}$ of the thiophosphane/benzimidazolium salts $2 \mathbf{c}, \mathbf{d}$ to give $3 \mathbf{c}, \mathbf{d}\left({ }^{31} \mathrm{P}\right.$ NMR monitoring). This is a first confirmation that steric crowding 
is more important in the benzimidazolium family, with possible implications in catalysis. As expected, upon deprotection of the diphenylthiophosphano group, the ${ }^{31} \mathrm{P}$ NMR signal of (benz)imidazolium salts shifted from $\delta c a .40 .5$ for 2 to $c a$. -27 for 53.

\section{Synthesis of palladium(II) complexes}

The synthesis and X-ray structural characterisation of complex $\mathbf{4 a}$, obtained by deprotonation of $\mathbf{3 a}$ both in racemic and enantiopure forms, has been previously published. $\$, 7$ We have now extended 10 this procedure to the synthesis of the analogous complexes with the NHC ligands obtained from $\mathbf{3 b}, \mathbf{3} \mathbf{c}$ and $\mathbf{3 d}$.

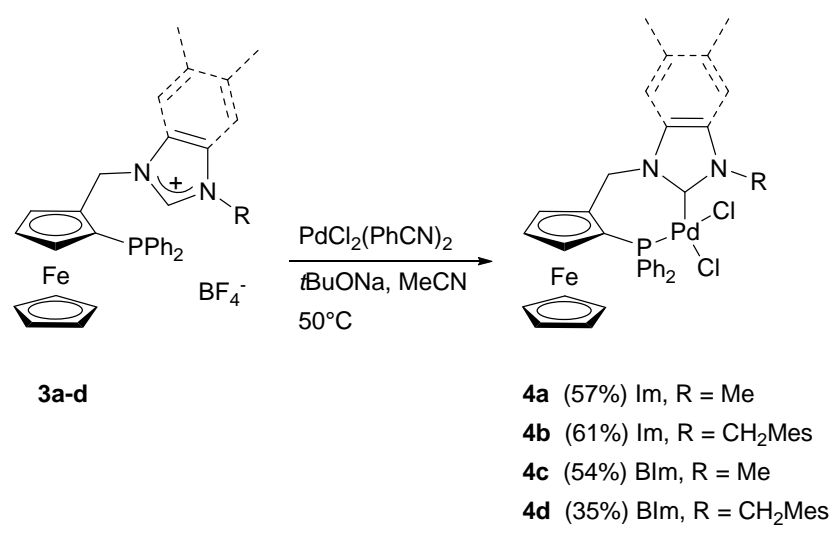

Scheme 3 Synthesis of neutral NHC-phosphane palladium(II) complexes.

15 All phosphane/(benz)imidazolium salts were deprotonated with $t \mathrm{BuONa}$ in the presence of the palladium precursor $\mathrm{PdCl}_{2}(\mathrm{PhCN})_{2}$ to give neutral $N$-heterocyclic carbene/phosphane palladium complexes $\mathbf{4 b}$-d in moderate yields. All products are air-stable and could be purified by column chromatography on silicagel. The 20 absence of the acidic proton characteristic of (benz)imidazolium salts in the ${ }^{1} \mathrm{H}$ NMR spectra indicated carbene formation. The ${ }^{31} \mathrm{P}$ NMR spectra of all complexes showed a major species with a signal between $\delta 3.86$ and 4.56 , along with $c a$. $2 \%$ of a second species around $\delta 15$. This minor species was obtained whatever the 25 complex and mass spectrometry analysis of the mixture by electrospray revealed a small amount of palladium dimer along with the expected monomeric structure. The carbenic carbon in ${ }^{13} \mathrm{C}$ NMR was found at $\delta 156.0$ for complex $\mathbf{4 b}$ bearing an imidazol-2ylidene moiety and went downfield for complexes $\mathbf{4 c , d}$ possessing 30 the benzimidazol-2-ylidene group with, respectively, $\delta 166.70$ and 166.74. The same trend has been observed for other neutral palladium(II) NHC complexes in the literature. ${ }^{21,22}$

The structures of all new complexes were established by X-ray crystallography and compared with that of $\mathbf{4 a} .^{7}$ The bond lengths 35 and angles are all within the expected range for neutral palladium complexes with a slightly distorted square-planar geometry (Figures 2 and 3, Table 1). Pd-C(NHC) (1.973(2) $\AA$, 4b, to 1.992(6) $\AA$, 4d) and Pd-P (2.2444(8) $\AA$, 4a, to 2.2546(19) $\AA$, 4d) bond lengths compare well with those in other previously ${ }_{40}$ published neutral palladium complexes bearing chelating $\mathrm{NHC} /$ phosphane ligands ${ }^{21,22}$ As observed previously for complex 4a, ${ }^{9}$ the $\mathrm{Pd}-\mathrm{Cl}$ bonds trans to the $\mathrm{NHC}$ are all slightly but significantly shorter than the $\mathrm{Pd}-\mathrm{Cl}$ bonds trans to the diphenylphosphano groups, which is surprising since the more

45 donating NHC should exert a greater trans influence than the phosphane, but this was also observed elsewhere. ${ }^{21,22}$ Similarly to the (benz)imidazolium salts, the $\mathrm{C}-\mathrm{C}$ bond of the heteroaromatic unit is slightly longer in the case of benzimidazol-2-ylidenes (1.372(5) $\AA$ for $\mathbf{4 c}$ and 1.391(8) $\AA$ for $\mathbf{4 d})$ than in the case of ${ }_{50}$ imidazol-2-ylidenes (1.350(6) $\AA$ for $\mathbf{4 a}$ and 1.345(4) $\AA$ for $\mathbf{4 b}$ ), which could denote some delocalisation of the double bond due to the presence of the fused benzene ring. No other significant differences in bond lengths are notable between the four structures. However, the C(NHC)-Pd-P bite angle is significantly narrower in ${ }_{55}$ complex $4 \mathbf{a}$ with $84.95(9)^{\circ}$ and increases with the steric bulkiness of the ligand to reach $91.94(19)^{\circ}$ in complex $\mathbf{4 d}$.

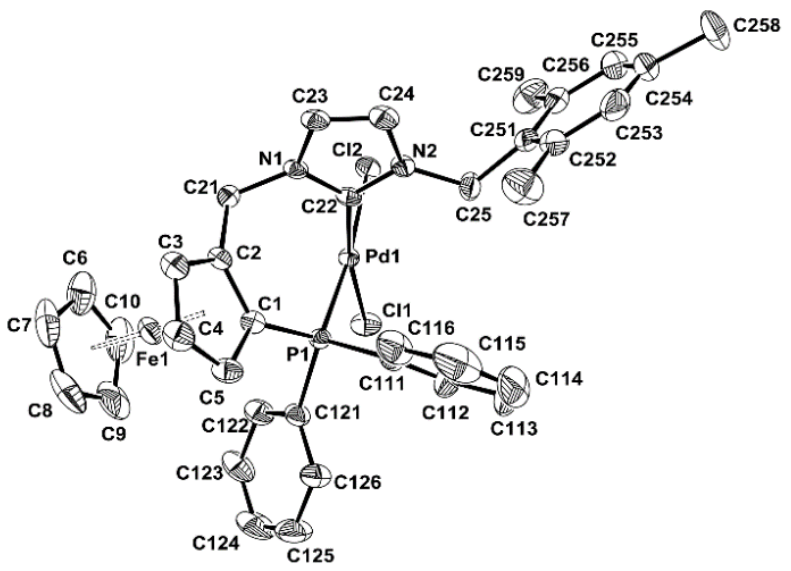

Fig. 2 ORTEP representation of complex $(S)$-4b. Ellipsoids are shown at the $50 \%$ level. All hydrogens are omitted for clarity.

60 Table 1 Selected distances $(\AA)$ and angles $\left({ }^{\circ}\right)$ for complexes $\mathbf{4 b}-\mathbf{d}$ and comparison with those of $\mathbf{4 a}{ }^{7}$

\begin{tabular}{ccccc}
\hline Distance $(\AA)$ & $\mathbf{4 a}$ & $\mathbf{4 b}$ & $\mathbf{4 c}$ & 4d \\
Pd-C(NHC) & $1.991(3)$ & $1.973(2)$ & $1.975(4)$ & $1.992(6)$ \\
Pd-P & $2.2444(8)$ & $2.2449(5)$ & $2.2475(9)$ & $2.2546(19)$ \\
Pd-Cl(trans-NHC) & $2.3397(8)$ & $2.3414(6)$ & $2.3043(12)$ & $2.3395(16)$ \\
Pd-Cl(trans-P) & $2.3614(9)$ & $2.3798(5)$ & $2.3347(10)$ & $2.3725(18)$ \\
C=C (NHC) & $1.350(6)$ & $1.345(4)$ & $1.372(5)$ & $1.391(8)$ \\
Angle ( $\left.{ }^{\circ}\right)$ & & & & \\
N-C(NHC)-N & $106.4(3)$ & $106.1(2)$ & $106.4(3)$ & $107.3(5)$ \\
C(NHC)-Pd-P & $84.95(9)$ & $88.90(6)$ & $89.94(10)$ & $91.94(19)$ \\
N-C $\left(\mathrm{CH}_{2}\right)-\mathrm{C}(\mathrm{Cp})$ & $112.2(3)$ & $109.22(19)$ & $111.1(3)$ & $110.7(5)$ \\
$\mathrm{N}-\mathrm{C}\left(\mathrm{CH}_{2}\right)-\mathrm{C}(\mathrm{Mes})$ & - & $115.3(2)$ & - & $114.7(5)$
\end{tabular}



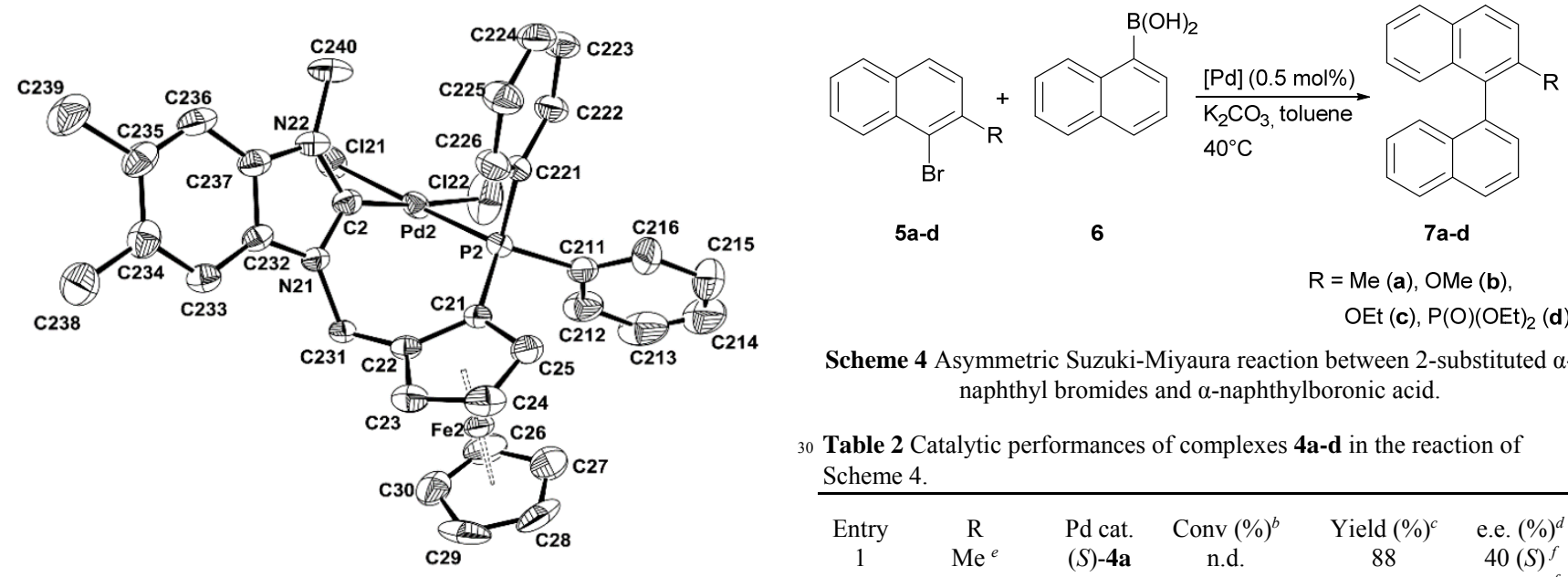

$\mathrm{R}=\mathrm{Me}(\mathbf{a}), \mathrm{OMe}(\mathbf{b})$

OEt (c), P(O)(OEt) 2 (d)

Scheme 4 Asymmetric Suzuki-Miyaura reaction between 2-substituted $\alpha$ naphthyl bromides and $\alpha$-naphthylboronic acid.

30 Table 2 Catalytic performances of complexes $\mathbf{4 a - d}$ in the reaction of Scheme 4.

\begin{tabular}{|c|c|c|c|c|c|}
\hline Entry & $\mathrm{R}$ & Pd cat. & Conv $(\%)^{b}$ & Yield $(\%)^{c}$ & e.e. $(\%)^{d}$ \\
\hline 1 & $\mathrm{Me}^{e}$ & $(S)-\mathbf{4 a}$ & n.d. & 88 & $40(S)^{f}$ \\
\hline 2 & & $(R)-\mathbf{4 a}$ & 95 & 88 & $42(R)^{f}$ \\
\hline 3 & & $(S)-\mathbf{4 b}$ & 63 & 58 & $46(S)$ \\
\hline 4 & & $(S)-4 c$ & 60 & 48 & $9(S)$ \\
\hline 5 & & $(S)-\mathbf{4 d}$ & 62 & 47 & $37(S)$ \\
\hline 6 & $\mathrm{OMe}$ & $(S)-\mathbf{4 a}$ & n.d. & 95 & $35(R)^{f}$ \\
\hline 7 & & $(R)-\mathbf{4 a}$ & n.d. & 93 & $33(S)^{f}$ \\
\hline 8 & & $(S)-\mathbf{4 b}$ & 88 & 65 & $31(R)$ \\
\hline 9 & & $(S)-4 c$ & 67 & 54 & $17(S)$ \\
\hline 10 & & $(S)-\mathbf{4 d}$ & 67 & 57 & $22(R)$ \\
\hline 11 & OEt & $(S)-\mathbf{4 a}$ & n.d. & 95 & $23(R)^{f}$ \\
\hline 12 & & $(R)-\mathbf{4 a}$ & n.d. & 92 & $24(S)^{f}$ \\
\hline 13 & & $(S)-\mathbf{4 b}$ & 22 & 22 & $26(R)$ \\
\hline 14 & & $(S)-4 c$ & 80 & 65 & $13(S)$ \\
\hline 15 & & $(S)-\mathbf{4 d}$ & 79 & 62 & $23(R)$ \\
\hline 16 & & $(S)-\mathbf{4 d}$ & 75 & 54 & $28(R)^{g}$ \\
\hline 17 & $\mathrm{P}(\mathrm{O})(\mathrm{OEt})_{2}$ & $(S)-\mathbf{4 a}$ & 26 & 0 & - \\
\hline 18 & & $(S)-\mathbf{4 b}$ & 28 & 0 & - \\
\hline 19 & & $(S)-4 \mathrm{c}$ & 35 & 0 & - \\
\hline 20 & & $(S)-\mathbf{4 d}$ & 8 & 0 & - \\
\hline
\end{tabular}

Fig.3 ORTEP representations of complexes (S)-4c (top) and rac-4d (bottom). Ellipsoids are shown at the $50 \%$ level. All hydrogens are omitted for clarity.

\section{Asymmetric Suzuki-Miyaura reaction}

Palladium(II) complexes $\mathbf{4 b}$-d were evaluated in the asymmetric version of the Suzuki-Miyaura cross-coupling reaction between naphthyl bromides and naphthylboronic acid. We previously

10 demonstrated that complex $\mathbf{4 a}$ is active for the coupling of substituted naphthyl bromides with naphthylboronic acid at low catalyst loadings and gives, as expected, similar levels of enantioselectivities with the $(R)$ and $(S)$ enantiomers. ${ }^{7}$ Therefore, the other complexes were tested directly under the same conditions 15 with the enantiomerically pure ligands possessing the $(S)$ configuration. As expected, all complexes are active for the coupling of various naphthyl bromides with a catalytic charge of $0.5 \mathrm{~mol} \%$ at $40^{\circ} \mathrm{C}$. All reactions were stopped after $24 \mathrm{~h}$ to maximise conversions and allow comparison of the results.

20 The first observation to be made is that steric hindrance in the catalyst indeed plays a role since for each reaction the product yield decreases as the steric crowding on the complex increases. Whereas 4a gives excellent yields of the expected coupling product for most substrates, $\mathbf{4 b}$ gives the products in only moderate yields 25 and the unexpectedly low yield for the ethoxy substrate cannot be rationally explained.

${ }^{a}$ Reagents and conditions: naphthyl bromide (1.0 equiv), boronic acid (1.2 equiv), Pd cat. ( $0.5 \mathrm{~mol} \%), \mathrm{K}_{2} \mathrm{CO}_{3}$ (2.4 equiv), toluene, $24 \mathrm{~h} .{ }^{b}$ Determined by integration of characteristic ${ }^{1} \mathrm{H}$ NMR signals in the crude 35 mixture. ${ }^{c}$ Isolated yield. ${ }^{d}$ Determined by HPLC with a Chiracel-OJ column. ${ }^{e}$ The commercial 1-bromo-2-methylnaphthalene contains ca. $6 \%$ of 2-methylnaphthalene. ${ }^{f}$ reference $7 .{ }^{g} 2 \mathrm{~mol} \%$ of Pd catalyst were used.

Complexes $\mathbf{4 c}$ and $\mathbf{4 d}$ bearing the more bulky benzimidazol-240 ylidene backbone also give moderate yields of the expected coupling products. Although the yields were low with all complexes except for $\mathbf{4 a}$, it seems that steric bulk could be slightly beneficial for the asymmetric induction in some cases, since slightly better e.e.s were obtained with $\mathbf{4 b}$ (up to $46 \%$ ), bearing a ${ }_{45} \mathrm{CH}_{2} \mathrm{Mes}$ substituent in place of a methyl group. Again, unexpectedly low e.e.s were obtained with complex $\mathbf{4 c}$, which cannot only be explained in terms of steric congestion since complex 4d, which possesses the bulkiest ligand, gives better e.e.s than complex 4c. Increasing the catalytic charge from $0.5 \mathrm{~mol} \%$ to ${ }_{50} 2 \mathrm{~mol} \%$ did not improve the level of enantioselectivity or the yield of coupling product (entry 16). The naphthyl bromide bearing a phosphonate substituent at the 2-position has been widely used in asymmetric Suzuki-Miyaura reactions and usually gives better e.e.s than other substrates, as it seems that a chelating functionality 55 on one coupling partner is beneficial to achieve good enantioselectivities. ${ }^{11,14}$ However, in our case none of the expected coupling product was obtained whatever the complex used, only a mixture of naphthyl bromide and the corresponding dehalogenated product. Hydrodehalogenation has already been observed in the 
conditions of the Suzuki-Miyaura coupling ${ }^{23}$ and this could indicate that the oxidative addition takes place but the following step, i.e. the transmetallation of the boronic acid, does not occur. One of the reasons could be the bulkiness of our ligands, but 5 chelating diphosphanes have also been reported not to give conclusive results with this substrate. ${ }^{13}$ Therefore, the chelating nature of our ligands, which have two strongly coordinating groups, could be detrimental to the reaction in certain cases.

Asymmetric 1,2-addition of phenylboronic acid to 410 nitrobenzaldehyde

The addition products such as diarylmethanols, are very important intermediates in the synthesis of biologically active compounds. ${ }^{24}$ This reaction has been well studied with rhodium complexes, with the first example of enantioselective 1,2-addition of boronic acids 15 to aldehydes described by Miyaura in $1998 .^{25}$ Diarylmethanols have thus been obtained with very good enantioselectivities (up to $94 \%$ ee), ${ }^{26}$ but the use of cheaper palladium complexes in the asymmetric version of this reaction is much less common. ${ }^{17-19}$ Indeed, only two recent examples show poor to moderate 20 enantioselectivities, using a planar chiral ferrocenyl phosphine (up to $11 \%$ ee) ${ }^{18}$ or axially chiral NHC ligands (up to $65 \%$ ee).$^{19} \mathrm{We}$ thus turned to the 1,2-addition of $\mathrm{PhB}(\mathrm{OH})_{2}$ to 4nitrobenzaldehyde, hoping to improve the previously measured enantioselectivities. As the synthesis of $\mathbf{4 a}$ is more straightforward

25 than that of $\mathbf{4 b} \mathbf{b}-\mathbf{d}$, we therefore carried out preliminary tests with enantiopure $(R)-\mathbf{4 a}$ only. The reaction was first conducted in THF using $\mathrm{KOH}$ as base and $5 \mathrm{~mol} \%$ of palladium complex (entry 1).

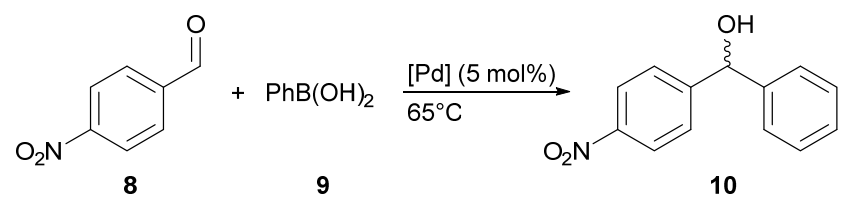

30 Scheme 4 1,2-Addition of phenylboronic acid to 4-nitrobenzaldehyde.

Table 3 Catalytic performances of complex $(R)-\mathbf{4 a}$ in the reaction of Scheme 5 .

\begin{tabular}{cccccc}
\hline Entry & $\mathrm{t}(\mathrm{h})$ & Solvent & Base & Yield $(\%)^{c}$ & E.e. $(\%)^{d}$ \\
$1^{a}$ & 24 & THF & $\mathrm{KOH}$ & 22 & $13(R)$ \\
$2^{b}$ & 24 & dioxane & $\mathrm{CsF}$ & 22 & $3(R)$ \\
$3^{b}$ & 4 & dioxane & $\mathrm{CsF}$ & 32 & $7(R)$ \\
$4^{b}$ & 24 & toluene & $\mathrm{K}_{2} \mathrm{CO}_{3}$ & 69 & $12(R)$ \\
$5^{b}$ & 4 & toluene & $\mathrm{K}_{2} \mathrm{CO}_{3}$ & 45 & $11(R)$
\end{tabular}

${ }^{a}$ Reagents and conditions: 4-Nitroenzaldehyde (1 equiv), phenylboronic acid ( 2 equiv), KOH ( 3 equiv), THF $(5 \mathrm{~mL}), 24 \mathrm{~h} .{ }^{b}$ Reagents and

35 conditions: 4-Nitroenzaldehyde ( 1 equiv), phenylboronic acid (1.5 equiv), base (2 equiv), solvent $(1 \mathrm{~mL}) .{ }^{c}$ Isolated yield. ${ }^{d}$ Determined by HPLC with a Chiracel-AD-H column and compared with published results. ${ }^{18,19}$

The selectivity with $\mathrm{THF} / \mathrm{KOH}$ was not satisfactory as a nonnegligible amount of 4-nitrobenzyl alcohol from the Canizzarro 40 reaction, as well as other minor by-products, were observed in the ${ }^{1} \mathrm{H}$ NMR spectrum of the crude mixture. Changing the solvent/base couple to dioxane/CsF was no better: although the ${ }^{1} \mathrm{H}$ NMR spectrum of the crude mixture showed almost complete consumption of the starting aldehyde, several unidentified by-

${ }_{45}$ products were also observed (entries 2,3 ). Only the toluene $/ \mathrm{K}_{2} \mathrm{CO}_{3}$ couple gave interesting results in terms of selectivity and yield (entries 4,5). Unfortunately, the levels of enantioselectivity measured for complex $(R)-\mathbf{4 a}$ were poor, with up to $13 \%$ e.e. in THF (entry 1), and are comparable to those obtained by Suzuma et ${ }_{50} \mathrm{al}^{1{ }^{18}}$ However, this is a preliminary work and a more thorough study of the reaction conditions with this and other chiral palladium complexes will be carried out in order to improve the efficiency of this challenging reaction.

\section{Conclusions}

${ }_{55}$ We have described in this paper the synthesis of a new family of chiral Pd complexes, containing enantiomerically pure phosphane/(benz)imidazol-2-ylidene ligands. A first application of these complexes to the asymmetric Suzuki-Miyaura reaction has revealed that the bulkiness of ferrocene conjugated with that of 60 benzimidazol-2-ylidene seems detrimental to the catalytic activity. The influence of the NHC structure on enantioselectivity is not entirely predictable and the best e.e. of $46 \%$ was obtained with $\mathbf{4 b}$, only a $4 \%$ improvement compared to the previously investigated complex 4a, and to the detriment of the yield. Preliminary tests in ${ }_{65}$ the catalysed 1,2-addition of phenylboronic acid to 4nitrobenzaldehyde with complex 4a showed moderate activities and low enantioselectivities. Future work will aim at designing other types of chiral functionalised $N$-heterocyclic carbenes in order to find the best compromise between activity and 70 enantioselectivity.

\section{Acknowledgements}

We thank the CNRS, the Ministère de l'Enseignement Supérieur et de la Recherche (doctoral grant to P.L.), the Institut Universitaire de France (grant to S.G.) and the Agence Nationale de la 75 Recherche (ANR-07-JCJC-0041, postdoctoral grant to N.D.) for financial support of this work.

\section{Experimental}

\section{General considerations}

All manipulations were performed under an inert atmosphere of 80 dry argon by using vacuum line and Schlenk tube techniques. Solvents for syntheses were dried and degassed by standard methods before use. 1D- and 2D-NMR spectra were recorded on Bruker AV500 and Bruker AV300 spectrometers. ${ }^{1} \mathrm{H}$ and ${ }^{13} \mathrm{C}$ chemicals shifts $(\delta)$ are given in ppm (the residual peak of ${ }_{85}$ deuterated solvent was used as reference). ${ }^{31} \mathrm{P}$ chemicals shifts are reported in ppm. Peaks are labeled as singlet (s), doublet (d), triplet $(\mathrm{t})$, multiplet $(\mathrm{m})$ and broad (br). The proton and carbon assignment were performed by COSY, NOESY, HSQC, ${ }^{1} \mathrm{H}-{ }^{13} \mathrm{C} \mathrm{HMBC},{ }^{1} \mathrm{H}-$ ${ }^{31} \mathrm{P}$ HMBC experiments. MS spectra were performed by the mass 90 spectrometry service of the Paul Sabatier University. Optical rotations were measured in a $1 \mathrm{dm}$ cell with a Perkin-Elmer 241 photopolarimeter. GC chromatograms were recorded on a HP 4890A GC equipped with a DB-5 MS UI capillary column and the products were identified by comparison with authentic samples. 95 HPLC chromatograms were recorded on a Shimadzu LC2010A(HT) equipped with a Chiralcel OJ column. Commercial chemicals were from Acros, Aldrich, Alfa Aesar, or Fluka and used as received. 1,2-Ferrocenyl alcohol $\mathbf{1},{ }^{27}$ imidazolium salts $\mathbf{2 a}, 3 \mathbf{a}^{5}$ and palladium complex $4 \mathbf{a}^{7}$ were prepared according to previously 100 reported procedures. Abbreviations: $\mathrm{Cp}_{\mathrm{A}}$ : cyclopentadienyl ring 
with $\mathrm{PPh}_{2}$ or $\mathrm{PPh}_{2}(=\mathrm{S})$ substituents; Срв: unsubstituted cyclopentadienyl ring; Fc: ferrocenyl; Im: imidazolyl; BIm: benzimidazolyl; Mes: mesityl. $\mathrm{C}^{\mathrm{q}}$ : quaternary carbon.

\section{Syntheses}

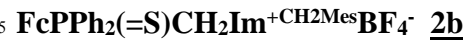

To a solution of ferrocenyl alcohol $\underline{\mathbf{1}}(100 \mathrm{mg}, 0.23 \mathrm{mmol})$ in dry $\mathrm{CH}_{2} \mathrm{Cl}_{2}(10 \mathrm{~mL})$ was quickly added $\mathrm{HBF}_{4}\left(54 \%\right.$ wt in $\mathrm{Et}_{2} \mathrm{O}, 50 \mu \mathrm{L}$, 0.35 mmol), immediately followed by $N-2,4,6$ trimethylbenzylimidazole $(110 \mathrm{mg}, 0.55 \mathrm{mmol})$. After 5 minutes, 10 the mixture was washed with $2 \mathrm{M}$ aq. $\mathrm{HCl}$, water, sat. aq. $\mathrm{NaHCO}_{3}$ and water, dried $\left(\mathrm{MgSO}_{4}\right)$, filtered and concentrated in vacuo. The residue was purified by precipitation with methyl tert-butyl ether from a $\mathrm{CH}_{2} \mathrm{Cl}_{2}$ solution to give a yellow solid $(80 \mathrm{mg}, 50 \%$ yield $)$. ${ }^{1} \mathrm{H}$ NMR $\left(300 \mathrm{MHz}, \mathrm{CDCl}_{3}, 298 \mathrm{~K}\right) \delta 8.61(1 \mathrm{H}, \mathrm{s}, \mathrm{NC} H \mathrm{~N}), 7.78-$ $157.71(2 \mathrm{H}, \mathrm{m}, \mathrm{CH} \mathrm{PPh}), 7.60-7.47$ (4H, m, CH PPh $), 7.40(1 \mathrm{H}, \mathrm{m}$, $\mathrm{CH} \mathrm{PPh} 2), 7.30(3 \mathrm{H}, \mathrm{m}, \mathrm{CH} \mathrm{PPh} 2), 7.15(1 \mathrm{H}, \mathrm{s}, \mathrm{CH} \mathrm{Mes}), 6.88(2 \mathrm{H}$, $\mathrm{s}, \mathrm{NCH}=\mathrm{CH}), 6.51(1 \mathrm{H}, \mathrm{s}, \mathrm{CH} \mathrm{Mes}), 6.40\left(1 \mathrm{H}, \mathrm{AB}\right.$ syst., $J_{\mathrm{HH}}=14$ $\left.\mathrm{Hz}, \mathrm{CH}_{2}-\mathrm{Fc}\right), 5.22\left(1 \mathrm{H}, \mathrm{AB}\right.$ syst., $\left.J_{\mathrm{HH}}=14 \mathrm{~Hz}, \mathrm{CH}_{2}-\mathrm{Fc}\right), 5.21(1 \mathrm{H}$, br. s, $\left.\mathrm{Cp}_{\mathrm{A}}\right), 5.14\left(1 \mathrm{H}, \mathrm{AB}\right.$ syst., $\left.J_{\mathrm{HH}}=14 \mathrm{~Hz}, \mathrm{CH}_{2}-\mathrm{Mes}\right), 4.91(1 \mathrm{H}$, 20 AB syst., $\left.J_{\mathrm{HH}}=14 \mathrm{~Hz}, \mathrm{CH}_{2}-\mathrm{Mes}\right), 4.53\left(1 \mathrm{H}\right.$, br. s, $\left.\mathrm{Cp}_{\mathrm{A}}\right), 4.35(5 \mathrm{H}$, $\left.\mathrm{s}, \mathrm{Cp} \mathrm{p}_{\mathrm{B}}\right), 3.86\left(1 \mathrm{H}\right.$, br s., $\left.\mathrm{Cp}_{\mathrm{A}}\right), 2.28\left(3 \mathrm{H}, \mathrm{s}, p-\mathrm{CH}_{3} \mathrm{Mes}\right), 2.13(6 \mathrm{H}$, $\left.\mathrm{s}, o-\mathrm{CH}_{3} \mathrm{Mes}\right) .{ }^{13} \mathrm{C}\left\{{ }^{1} \mathrm{H}\right\} \mathrm{NMR}\left(75.5 \mathrm{MHz}, \mathrm{CDCl}_{3}, 298 \mathrm{~K}\right) \delta 139.88$ ( $\mathrm{C}^{\mathrm{q}} \mathrm{Mes}, C-\mathrm{CH}_{2}$ ), 137.93 (2 $\left.\mathrm{C}^{\mathrm{q}} \mathrm{Mes}, C-o-\mathrm{CH}_{3}\right), 134.91(\mathrm{NCHN})$, $134.66\left(\mathrm{~d}, J_{\mathrm{CP}}=86 \mathrm{~Hz}, \mathrm{C}^{\mathrm{q}} \mathrm{PPh}_{2}\right), 132.08\left(\mathrm{~d}, J_{\mathrm{CP}}=56 \mathrm{~Hz}, \mathrm{C}^{\mathrm{q}} \mathrm{PPh}_{2}\right)$, ${ }_{25} 131.90\left(\mathrm{~d}, J_{\mathrm{CP}}=11 \mathrm{~Hz}, \mathrm{CH} \mathrm{PPh}_{2}\right), 131.70\left(\mathrm{~d}, J_{\mathrm{CP}}=3 \mathrm{~Hz}, \mathrm{CH} \mathrm{PPh}_{2}\right)$, $131.25\left(\mathrm{~d}, J_{\mathrm{CP}}=10 \mathrm{~Hz}, \mathrm{CH} \mathrm{PPh}_{2}\right), 129.89(2 \mathrm{CH}, \mathrm{NCH}=\mathrm{CH})$, $128.47\left(\mathrm{~d}, J_{\mathrm{CP}}=11 \mathrm{~Hz}, \mathrm{CH} \mathrm{PPh}\right), 128.33\left(\mathrm{~d}, J_{\mathrm{CP}}=12 \mathrm{~Hz}, \mathrm{CH} \mathrm{PPh} 2\right)$, 125.35 ( $\left.\mathrm{C}^{\mathrm{q}} \mathrm{Mes}, C-p-\mathrm{CH}_{3}\right), 122.04$ (CH Mes), 120.24 (CH Mes), $83.44\left(\mathrm{~d}, J_{\mathrm{CP}}=12 \mathrm{~Hz}, \mathrm{C}^{\mathrm{q}} \mathrm{Cp}_{\mathrm{A}}\right), 76.76\left(\mathrm{~d}, J_{\mathrm{CP}}=10 \mathrm{~Hz}, \mathrm{CH} \mathrm{Cp}_{\mathrm{A}}\right), 76.00$ ${ }_{30}\left(\mathrm{~d}, J_{\mathrm{CP}}=11 \mathrm{~Hz}, \mathrm{CH} \mathrm{Cp}_{\mathrm{A}}\right), 73.55\left(\mathrm{~d}, J_{\mathrm{CP}}=93 \mathrm{~Hz}, \mathrm{C}^{\mathrm{q}} \mathrm{Cp}_{\mathrm{A}}\right), 71.39$ (d, $\left.J_{\mathrm{CP}}=9 \mathrm{~Hz}, \mathrm{CH} \mathrm{Cp}_{\mathrm{A}}\right), 71.23(5 \mathrm{CH}$ Cpв$), 47.91\left(\mathrm{CH}_{2}-\mathrm{Fc}\right.$ or $\mathrm{CH}_{2}-$ Mes), $47.40\left(\mathrm{CH}_{2}-\mathrm{Fc}\right.$ or $\left.\mathrm{CH}_{2}-\mathrm{Mes}\right), 21.04$ ( $p$ - $\left.\mathrm{CH}_{3} \mathrm{Mes}\right), 19.61$ (o$\left.\mathrm{CH}_{3} \mathrm{Mes}\right) .{ }^{31} \mathrm{P}\left\{{ }^{1} \mathrm{H}\right\}$ NMR $\left(121 \mathrm{MHz}, \mathrm{CDCl}_{3}, 298 \mathrm{~K}\right) \delta 40.65$. MS (ESI) $\mathrm{m} / \mathrm{z} 615\left[\mathrm{M}^{+}\right]$(100), $415\left[\mathrm{M}^{+}-\mathrm{C}_{13} \mathrm{H}_{16} \mathrm{~N}_{2}\right]$ (8). HRMS (ES $\left.{ }^{+}\right)$ 35 calcd for $\mathrm{C}_{36} \mathrm{H}_{36} \mathrm{~N}_{2} \mathrm{PSFe} 615.1687$; found 615.1688. (S)-2b: $[\alpha]^{20}{ }_{D}=-11\left(\mathrm{c}=0.55, \mathrm{CH}_{2} \mathrm{Cl}_{2}\right)$.

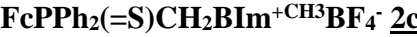

To a solution of ferrocenyl alcohol $\underline{\mathbf{1}}(418 \mathrm{mg}, 0.97 \mathrm{mmol})$ in dry $\mathrm{CH}_{2} \mathrm{Cl}_{2}(20 \mathrm{~mL})$ was quickly added $\mathrm{HBF}_{4}\left(54 \%\right.$ wt in $\mathrm{Et}_{2} \mathrm{O}, 330$

$40 \mu \mathrm{L}, 2.42 \mathrm{mmol}$ ), immediately followed by $N$-methyl benzimidazole ( $466 \mathrm{mg}, 2.91 \mathrm{mmol}$ ). After 5 minutes, the mixture was washed with $2 \mathrm{M}$ aq. $\mathrm{HCl}$, water, sat. aq. $\mathrm{NaHCO}_{3}$ and water, dried $\left(\mathrm{MgSO}_{4}\right)$, filtered and concentrated in vacuo. The residue was purified by precipitation with a mixture of petroleum ether and 45 methyl tert-butyl ether (80/20) from a $\mathrm{CH}_{2} \mathrm{Cl}_{2}$ solution to give an orange solid (193 mg, 27\% yield). X-ray quality crystals of rac-2c were obtained by slow diffusion of diethyl-ether from a dichloromethane solution. ${ }^{1} \mathrm{H}$ NMR $\left(300 \mathrm{MHz}, \mathrm{CDCl}_{3}, 298 \mathrm{~K}\right) \delta$ $8.79(1 \mathrm{H}, \mathrm{s}, \mathrm{NCHN}), 7.73-7.69(3 \mathrm{H}, \mathrm{m}, \mathrm{CH} \mathrm{PPh} 2+\mathrm{BIm}), 7.55-7.47$ ${ }_{50}(4 \mathrm{H}, \mathrm{m}, \mathrm{CH} \mathrm{PPh}), 7.21-7.15(3 \mathrm{H}, \mathrm{m}, \mathrm{CH} \mathrm{PPh} 2), 6.95-6.93(3 \mathrm{H}, \mathrm{m}$, $\mathrm{CH} \mathrm{PPh} 2+\mathrm{BIm}), 6.57\left(1 \mathrm{H}, \mathrm{AB}\right.$ syst., $\left.J_{\mathrm{HH}}=14 \mathrm{~Hz}, \mathrm{Fc}-\mathrm{CH}_{2}\right), 5.23$ $(1 \mathrm{H}$, br. $\mathrm{s}, \mathrm{Cp} \mathrm{A}), 5.21\left(1 \mathrm{H}, \mathrm{AB}\right.$ syst., $\left.J_{\mathrm{HH}}=14 \mathrm{~Hz}, \mathrm{Fc}-\mathrm{CH}_{2}\right), 4.58$ $\left(1 \mathrm{H}\right.$, br. s, $\left.\mathrm{Cp}_{\mathrm{A}}\right), 4.48(5 \mathrm{H}, \mathrm{s}, \mathrm{Cp}), 3.78\left(1 \mathrm{H}\right.$, br. $\left.\mathrm{s}, \mathrm{Cp}_{\mathrm{A}}\right), 3.64(3 \mathrm{H}$, s, $\left.\mathrm{NCH}_{3}\right), 2.37\left(3 \mathrm{H}, \mathrm{s}, \mathrm{CH}_{3} \mathrm{BIm}\right), 2.16\left(3 \mathrm{H}, \mathrm{s}, \mathrm{CH}_{3} \mathrm{BIm}\right) .{ }^{13} \mathrm{C}\left\{{ }^{1} \mathrm{H}\right\}$ $55 \mathrm{NMR} \quad\left(75.5 \mathrm{MHz}, \mathrm{CDCl}_{3}, 298 \mathrm{~K}\right) \quad \delta \quad 140.47 \quad(\mathrm{NCHN})$, $136.95+136.98\left(\mathrm{C}^{\mathrm{q}} \mathrm{BIm}\right), 133.08\left(\mathrm{~d}, J_{\mathrm{CP}}=80 \mathrm{~Hz}, \mathrm{C}^{\mathrm{q}} \mathrm{PPh}_{2}\right), 131.99$ $\left(\mathrm{d}, J_{\mathrm{CP}}=86 \mathrm{~Hz}, \mathrm{C}^{\mathrm{q}} \mathrm{PPh}_{2}\right), 131.85$ (d, $\left.J_{\mathrm{CP}}=2 \mathrm{~Hz}, \mathrm{CH} \mathrm{PPh}_{2}\right), 131.77$ $\left(\mathrm{d}, J_{\mathrm{CP}}=12 \mathrm{~Hz}, \mathrm{CH} \mathrm{PPh}_{2}\right), 131.25$ (d, $\left.J_{\mathrm{CP}}=11 \mathrm{~Hz}, \mathrm{CH} \mathrm{PPh} 2\right), 130.94$ (d, $\left.J_{\mathrm{CP}}=2 \mathrm{~Hz}, \mathrm{CH} \mathrm{PPh}_{2}\right), 129.78+129.24\left(\mathrm{C}^{\mathrm{q}} \mathrm{BIm}\right), 128.34$ (d, $\left.{ }_{60} J_{\mathrm{CP}}=13 \mathrm{~Hz}, \mathrm{CH} \mathrm{PPh}_{2}\right), 127.61\left(\mathrm{~d}, J_{\mathrm{CP}}=12 \mathrm{~Hz}, \mathrm{CH} \mathrm{PPh}_{2}\right)$, 114.22+111.58 (CH BIm), 82.37 (d, $\left.J_{\mathrm{CP}}=13 \mathrm{~Hz}, \mathrm{C}^{\mathrm{q}} \mathrm{Cp}_{\mathrm{A}}\right), 77.24$ $\left(\mathrm{CH} \mathrm{Cp}_{\mathrm{A}}\right), 76.38\left(\mathrm{~d}, J_{\mathrm{CP}}=10 \mathrm{~Hz}, \mathrm{CH} \mathrm{Cp} \mathrm{A}_{\mathrm{A}}\right), 75.27\left(\mathrm{~d}, J_{\mathrm{CP}}=91 \mathrm{~Hz}, \mathrm{C}^{\mathrm{q}}\right.$ $\left.\mathrm{Cp}_{\mathrm{A}}\right), 71.39\left(5 \mathrm{CH} \mathrm{C} \mathrm{p}_{\mathrm{B}}\right), 71.18\left(\mathrm{~d}, J_{\mathrm{CP}}=10 \mathrm{~Hz}, \mathrm{CH} \mathrm{Cp} \mathrm{p}_{\mathrm{A}}\right), 45.60$ $\left(\mathrm{CH}_{2}-\mathrm{Fc}\right), 33.37\left(\mathrm{NCH}_{3}\right), 20.64+20.52\left(\mathrm{CH}_{3} \mathrm{BIm}\right) .{ }^{31} \mathrm{P}\left\{{ }^{1} \mathrm{H}\right\} \mathrm{NMR}$ ${ }_{65}\left(121.5 \mathrm{MHz}, \mathrm{CDCl}_{3}, 298 \mathrm{~K}\right) \delta 40.34$. MS (ESI) $\mathrm{m} / \mathrm{z} 575\left[\mathrm{M}^{+}\right]$(100), $415\left[\mathrm{M}^{+}-\mathrm{C}_{10} \mathrm{H}_{12} \mathrm{~N}_{2}\right]$ (18). HRMS $\left(\mathrm{ES}^{+}\right)$calcd for $\mathrm{C}_{33} \mathrm{H}_{32} \mathrm{~N}_{2} \mathrm{PSFe}$ 575.1374; found 575.1367. (S)-2c: $[\alpha]^{20} \mathrm{D}^{=-81}\left(\mathrm{c}=0.54, \mathrm{CH}_{2} \mathrm{Cl}_{2}\right)$.

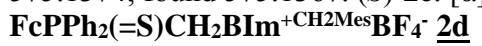

To a solution of ferrocenyl alcohol $\underline{\mathbf{1}}(474 \mathrm{mg}, 1.09 \mathrm{mmol})$ in dry ${ }_{70} \mathrm{CH}_{2} \mathrm{Cl}_{2}(20 \mathrm{~mL})$ was quickly added $\mathrm{HBF}_{4}\left(54 \%\right.$ wt in $\mathrm{Et}_{2} \mathrm{O}, 380$ $\mu \mathrm{L}(2.75 \mathrm{mmol}, 2.5$ equiv), immediately followed by $N-2,4,6$ trimethylbenzyl benzimidazole ( $800 \mathrm{mg}, 2.88 \mathrm{mmol}, 2.7$ equiv). After 5 minutes, the mixture was washed with $2 \mathrm{M}$ aq. $\mathrm{HCl}$, water, sat. aq. $\mathrm{NaHCO}_{3}$ and water, dried $\left(\mathrm{MgSO}_{4}\right)$, filtered and 75 concentrated in vacuo. The residue was purified by precipitation with a mixture of petroleum ether and methyl tert-butyl ether (80/20) from a $\mathrm{CH}_{2} \mathrm{Cl}_{2}$ solution, followed by column chromatography on silica gel (eluents: diethyl ether, then $\mathrm{CH}_{2} \mathrm{Cl}_{2}$, then $\mathrm{CH}_{2} \mathrm{Cl}_{2} /$ Acetone 90/10) to give an orange solid (481 mg, 57\% 80 yield). X-ray quality crystals of $\mathrm{rac}-\mathbf{2 d}$ were obtained by slow diffusion of diethyl ether into a dichloromethane solution. ${ }^{1} \mathrm{H}$ NMR $\left(500 \mathrm{MHz}, \mathrm{CDCl}_{3}, 301 \mathrm{~K}\right) \delta 8.68(1 \mathrm{H}, \mathrm{s}, \mathrm{NCHN}), 7.72-7.68(3 \mathrm{H}$, $\mathrm{m}, \mathrm{CH} \mathrm{PPh} 2+\mathrm{BIm}), 7.58-7.55\left(1 \mathrm{H}, \mathrm{m}, \mathrm{CH} \mathrm{PPh}_{2}\right), 7.51-7.47(2 \mathrm{H}$, $\left.\mathrm{m}, \mathrm{CH} \mathrm{PPh}_{2}\right), 7.22-7.18(1 \mathrm{H}, \mathrm{m}, \mathrm{CH} \mathrm{PPh} 2), 7.07-7.00(3 \mathrm{H}, \mathrm{m}, \mathrm{CH}$ $\left.{ }_{85} \mathrm{PPh}_{2}+\mathrm{BIm}\right), 6.94$ (2H, s, CH Mes), 6.90-6.85 (2H, m, CH PPh2), $6.48\left(1 \mathrm{H}, \mathrm{AB}\right.$ syst., $\left.\mathrm{Fc}-\mathrm{CH}_{2}\right), 5.51\left(1 \mathrm{H}, \mathrm{AB}\right.$ syst., $\left.\mathrm{Fc}-\mathrm{CH}_{2}\right), 5.40$ $(1 \mathrm{H}, \mathrm{br}, \mathrm{Cp} \mathrm{A}), 5.32\left(1 \mathrm{H}, \mathrm{AB}\right.$ syst., $\left.\mathrm{CH}_{2}-\mathrm{Mes}\right), 4.98$ (1H, AB syst., $\left.\mathrm{CH}_{2}-\mathrm{Mes}\right), 4.57\left(1 \mathrm{H}\right.$, br s, $\left.\mathrm{Cp}_{\mathrm{A}}\right), 4.42\left(5 \mathrm{H}, \mathrm{s}, \mathrm{Cp}_{\mathrm{B}}\right), 3.81(1 \mathrm{H}, \mathrm{s}$, $\mathrm{Cp}_{\mathrm{A}}$ ), 2.34-2.33 (9H, m, CH $\left.3 \mathrm{BIm}+p-\mathrm{CH}_{3} \mathrm{Mes}\right), 2.17\left(6 \mathrm{H}, \mathrm{s}, o-\mathrm{CH}_{3}\right.$ $90 \mathrm{Mes}) .{ }^{13} \mathrm{C} \mathrm{NMR}\left\{{ }^{1} \mathrm{H}\right\}\left(125.8 \mathrm{MHz}, \mathrm{CDCl}_{3}, 301 \mathrm{~K}\right) \delta 139.97\left(\mathrm{C}^{\mathrm{q}} p-\right.$ $\mathrm{CH}_{3} \mathrm{C}$ Mes), 139.51 (NCHN), $137.94 \quad\left(\mathrm{C}^{\mathrm{q}} \quad o-\mathrm{CH}_{3} \mathrm{C}\right.$ Mes), 137.23+137.20 ( $\left.\mathrm{C}^{\mathrm{q}} \mathrm{CH}_{3} C \mathrm{BIm}\right), 134.01\left(\mathrm{~d}, J_{\mathrm{CP}}=86 \mathrm{~Hz}, \mathrm{C}^{\mathrm{q}} \mathrm{PPh}_{2}\right)$, $132.00\left(\mathrm{~d}, J_{\mathrm{CP}}=11 \mathrm{~Hz}, \mathrm{CH} \mathrm{PPh}_{2}\right), 131.99\left(\mathrm{~d}, J_{\mathrm{CP}}=87 \mathrm{~Hz}, \mathrm{C}^{\mathrm{q}} \mathrm{PPh}_{2}\right)$, $131.92\left(\mathrm{~d}, J_{\mathrm{CP}}=3 \mathrm{~Hz}, \mathrm{CH} \mathrm{PPh}_{2}\right), 131.20\left(\mathrm{~d}, J_{\mathrm{CP}}=3 \mathrm{~Hz}, \mathrm{CH} \mathrm{PPh}_{2}\right)$, $95130.83\left(\mathrm{~d}, \quad J_{\mathrm{CP}}=11 \mathrm{~Hz}, \quad \mathrm{CH} \quad \mathrm{PPh}_{2}\right), 130.07 \quad(\mathrm{CH}$ Mes $)$, $129.72+129.60\left(\mathrm{C}^{\mathrm{q}} \mathrm{BIm}\right), 128.66\left(\mathrm{~d}, J_{\mathrm{CP}}=13 \mathrm{~Hz}, \mathrm{CH} \mathrm{PPh}\right), 127.75$ (d, $\left.J_{\mathrm{CP}}=12 \mathrm{~Hz}, \quad \mathrm{CH} \quad \mathrm{PPh}_{2}\right), 124.95 \quad\left(\mathrm{C}^{\mathrm{q}} \mathrm{NCH}_{2} \mathrm{C} \quad \mathrm{Mes}\right)$, 114.79+112.33 (CH BIm), 83.05 (d, $\left.J_{\mathrm{CP}}=12 \mathrm{~Hz}, \mathrm{C}^{\mathrm{q}} \mathrm{Cp}_{\mathrm{A}}\right), 77.28$ $\left(\mathrm{CH} \mathrm{Cp}_{\mathrm{A}}\right.$, seen by HSQC $\left.\{31 \mathrm{P}\}\right), 76.12\left(\mathrm{~d}, J_{\mathrm{CP}}=12 \mathrm{~Hz}, \mathrm{CH} \mathrm{Cp}_{\mathrm{A}}\right)$, $10073.91\left(\mathrm{~d}, J_{\mathrm{CP}}=94 \mathrm{~Hz}, \mathrm{C}^{\mathrm{q}} \mathrm{Cp}_{\mathrm{A}}\right), 71.59(\mathrm{CH} \mathrm{Cp}), 71.17\left(\mathrm{~d}, J_{\mathrm{CP}}=10\right.$ $\mathrm{Hz}, \mathrm{CH} \mathrm{Cp} A), 46.72\left(\mathrm{CH}_{2}-\mathrm{Fc}\right), 45.77\left(\mathrm{CH}_{2}-\mathrm{Mes}\right), 21.10\left(p-\mathrm{CH}_{3}\right.$ Mes), 20.73+20.69 $\left(\mathrm{CH}_{3} \mathrm{BIm}\right), 20.03\left(o-\mathrm{CH}_{3} \mathrm{Mes}\right) .{ }^{31} \mathrm{P}\left\{{ }^{1} \mathrm{H}\right\} \mathrm{NMR}$ (202.5 MHz, $\left.\mathrm{CDCl}_{3}, 301 \mathrm{~K}\right) \delta 40.88$. MS (ESI) m/z $693\left[\mathrm{M}^{+}\right](100)$. HRMS $\left(\mathrm{ES}^{+}\right.$) calcd for $\mathrm{C}_{42} \mathrm{H}_{42} \mathrm{~N}_{2} \mathrm{PSFe}$ 693.2156; found 693.2164 . $105(S)$-2d: $[\alpha]^{20}{ }_{D}=-158\left(\mathrm{c}=0.53, \mathrm{CH}_{2} \mathrm{Cl}_{2}\right)$.

General procedure for the synthesis of (benz)imidazolium salts $\mathbf{F c P P h}_{2} \mathbf{C H}_{2} \mathbf{I m} / \mathbf{B I m}^{+\mathbf{R}} \mathbf{B F}_{4}^{-}$3b-d: Raney nickel (50 to 100 equivalents) was washed with degassed methanol (3 X $10 \mathrm{~mL})$, degassed diethyl ether ( 3 X $10 \mathrm{~mL})$ and, finally degassed 110 acetonitrile $(3 \mathrm{X} 10 \mathrm{~mL})$. A solution of (benz)imidazolium salt $\mathbf{2 b}$ d in acetonitrile $(20 \mathrm{~mL})$ was added and the mixture was heated at $40^{\circ} \mathrm{C}$ for $20 \mathrm{~h}$. After cooling to room temperature, the supernatant was filtered through a short path of Celite ${ }^{\circledR}$ and the Raney nickel was rinsed with acetonitrile. The filtrate was concentrated and the 115 solid residue was dried in vacuo.

$\mathbf{F C P P h}_{2} \mathbf{C H}_{2} \mathbf{I m}^{+\mathbf{C H}_{2} \mathrm{Mes}} \mathbf{B F}_{4}{ }^{-}$3b: yellow solid (220 $\mathrm{mg}, 88 \%$ yield). ${ }^{1} \mathrm{H}$ NMR (300 MHz, $\left.\mathrm{CDCl}_{3}, 298 \mathrm{~K}\right) \delta 8.73(1 \mathrm{H}, \mathrm{s}, \mathrm{NCHN})$, 
7.49 (2H, m, CH PPh $), 7.39$ (3H, m, CH PPh $), 7.16$ (3H, m, CH $\left.\mathrm{PPh}_{2}\right), 6.97\left(2 \mathrm{H}, \mathrm{m}, \mathrm{CH} \mathrm{PPh}_{2}\right), 6.87(2 \mathrm{H}, \mathrm{br} \mathrm{s}, \mathrm{CH} \mathrm{Mes}), 6.82(1 \mathrm{H}$, br s, $\mathrm{NCH}=\mathrm{CH}), 6.42(1 \mathrm{H}$, br s, $\mathrm{NCH}=\mathrm{CH}), 5.50(1 \mathrm{H}, \mathrm{AB}$ syst., $\left.J_{\mathrm{HH}}=15 \mathrm{~Hz}, \mathrm{CH}_{2}-\mathrm{Fc}\right), 5.37\left(1 \mathrm{H}, \mathrm{AB}\right.$ syst., $\left.J_{\mathrm{HH}}=15 \mathrm{~Hz}, \mathrm{CH}_{2}-\mathrm{Fc}\right)$, 5 $5.09\left(2 \mathrm{H}, \mathrm{s}, \mathrm{CH}_{2}-\mathrm{Mes}\right), 4.93(1 \mathrm{H}$, br s, $\mathrm{CH} \mathrm{Cp}$ ), $4.48(1 \mathrm{H}, \mathrm{br} \mathrm{s}$, $\left.\mathrm{CH} \mathrm{Cp} \mathrm{A}_{\mathrm{A}}\right), 4.11\left(5 \mathrm{H}, \mathrm{s}, \mathrm{CH} \mathrm{Cp} \mathrm{p}_{\mathrm{B}}\right), 3.92(1 \mathrm{H}, \mathrm{br} \mathrm{s}, \mathrm{CH} \mathrm{Cp} \mathrm{A}), 2.27(3 \mathrm{H}$, s, $\left.p-\mathrm{CH}_{3} \mathrm{Mes}\right), 2.01\left(6 \mathrm{H}, \mathrm{s}, o-\mathrm{CH}_{3} \mathrm{Mes}\right) .{ }^{13} \mathrm{C}\left\{{ }^{1} \mathrm{H}\right\}$ NMR $(75.5$ $\left.\mathrm{MHz} \mathrm{CDCl}_{3}, 298 \mathrm{~K}\right) \delta 139.98\left(\mathrm{C}^{\mathrm{q}} \mathrm{Mes}\right), 138.94\left(\mathrm{~d}, J_{\mathrm{CP}}=7 \mathrm{~Hz}, \mathrm{C}^{\mathrm{q}}\right.$ $\mathrm{PPh}_{2}$ ), 138.00 ( $\left.\mathrm{C}^{\mathrm{q}} \mathrm{Mes}\right), 135.56$ (d, $\left.J_{\mathrm{CP}}=7 \mathrm{~Hz}, \mathrm{C}^{\mathrm{q}} \mathrm{PPh}_{2}\right), 135.10$ $10(\mathrm{NCHN}), 134.71\left(\mathrm{~d}, J_{\mathrm{CP}}=21 \mathrm{~Hz}, \mathrm{CH} \mathrm{PPh}_{2}\right), 132.19$ (d, $J_{\mathrm{CP}}=19 \mathrm{~Hz}$, CH PPh 2 ), 129.89 (CH Mes), 129.68 (CH Mes), 128.43 (d, $J_{\mathrm{CP}}=8$ $\left.\mathrm{Hz}, \mathrm{CH} \mathrm{PPh}_{2}\right), 128.32$ (d, $\left.J_{\mathrm{CP}}=7 \mathrm{~Hz}, \mathrm{CH} \mathrm{PPh}_{2}\right), 124.93$ (C $\left.\mathrm{C}^{\mathrm{q}} \mathrm{Mes}\right)$, $121.48(\mathrm{NCH}=\mathrm{CH}), 120.06(\mathrm{NCH}=\mathrm{CH}), 84.23\left(\mathrm{~d}, J_{\mathrm{CP}}=28 \mathrm{~Hz}, \mathrm{C}^{\mathrm{q}}\right.$ $\left.\mathrm{Cp}_{\mathrm{A}}\right), 76.92\left(\mathrm{~d}, J_{\mathrm{CP}}=9 \mathrm{~Hz}, \mathrm{C}^{\mathrm{q}} \mathrm{Cp}_{\mathrm{A}}\right), 73.73\left(\mathrm{CH} \mathrm{Cp} \mathrm{p}_{\mathrm{A}}\right), 72.93(\mathrm{~d}$,

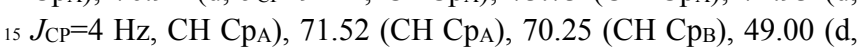
$\left.J_{\mathrm{CP}}=11 \mathrm{~Hz}, \mathrm{CH}_{2}-\mathrm{Fc}\right), 47.40$ ( $\left.\mathrm{CH}_{2}-\mathrm{Mes}\right), 22.63$ ( $\left.p-\mathrm{CH}_{3} \mathrm{Mes}\right), 21.01$ (o- $\left.\mathrm{CH}_{3} \mathrm{Mes}\right) .{ }^{31} \mathrm{P}\left\{{ }^{1} \mathrm{H}\right\} \mathrm{NMR}\left(121.5 \mathrm{MHz}, \mathrm{CDCl}_{3}, 298 \mathrm{~K}\right): \delta-$ 27.18. MS (ESI) m/z $583\left[\mathrm{M}^{+}\right]$(85) $383\left[\mathrm{M}^{+}-\mathrm{C}_{13} \mathrm{H}_{16} \mathrm{~N}_{2}\right]$ (100). HRMS $\left(\mathrm{ES}^{+}\right.$) calcd for $\mathrm{C}_{36} \mathrm{H}_{36} \mathrm{~N}_{2} \mathrm{PFe} 583.1966$; found 583.1962. $20(S)-3 \mathbf{b}:[\alpha]^{20}{ }_{D}=-161\left(\mathrm{c}=0.51, \mathrm{CH}_{2} \mathrm{Cl}_{2}\right)$.

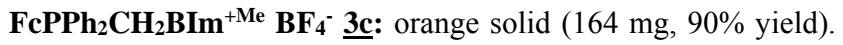
${ }^{1} \mathrm{H}$ NMR $\left(300 \mathrm{MHz}, \mathrm{CDCl}_{3}, 298 \mathrm{~K}\right) \delta 8.75(1 \mathrm{H}, \mathrm{s}, \mathrm{NCHN}), 7.51$ (1H, s, CH BIm), 7.46-7.37 (4H, m, CH PPh $), 7.28(1 \mathrm{H}, \mathrm{s}, \mathrm{CH}$ $\left.\mathrm{PPh}_{2}\right), 7.08$ (1H, s, CH BIm), 7.01 (1H, m, CH PPh $), 6.83(2 \mathrm{H}, \mathrm{m}$, $\left.{ }_{25} \mathrm{CH} \mathrm{PPh}_{2}\right), 6.65(2 \mathrm{H}, \mathrm{m}, \mathrm{CH} \mathrm{PPh}), 5.79\left(1 \mathrm{H}, \mathrm{AB}\right.$ syst., $J_{\mathrm{HH}}=15 \mathrm{~Hz}$, $\left.\mathrm{CH}_{2}-\mathrm{Fc}\right), 5.34\left(1 \mathrm{H}, \mathrm{AB}\right.$ syst., $\left.J_{\mathrm{HH}}=15 \mathrm{~Hz}, \mathrm{CH}_{2}-\mathrm{Fc}\right), 5.06(1 \mathrm{H}$, br s, CH Cp $\left.\mathrm{p}_{\mathrm{A}}\right), 4.50\left(1 \mathrm{H}, \mathrm{br} \mathrm{s}, \mathrm{CH} \mathrm{Cp}_{\mathrm{A}}\right), 4.22(5 \mathrm{H}, \mathrm{s}, \mathrm{CH} \mathrm{CpB}), 3.84(1 \mathrm{H}$, br s, $\left.\mathrm{Cp}_{\mathrm{A}}\right), 3.67\left(3 \mathrm{H}, \mathrm{s}, \mathrm{N}-\mathrm{CH}_{3}\right), 2.37\left(6 \mathrm{H}\right.$, br s, $\left.\mathrm{CH}_{3} \mathrm{BIm}\right) .{ }^{13} \mathrm{C}\left\{{ }^{1} \mathrm{H}\right\}$ $\mathrm{NMR}\left(75 \mathrm{MHz}, \mathrm{CDCl}_{3}, 298 \mathrm{~K}\right) \delta 140.35(\mathrm{NCHN}), 138.10\left(\mathrm{~d}, J_{\mathrm{CP}}=7\right.$ $\left.30 \mathrm{~Hz}, \mathrm{C}^{\mathrm{q}} \mathrm{PPh}_{2}\right), 136.92\left(\mathrm{C}^{\mathrm{q}} \mathrm{CH}_{3} \mathrm{C} \mathrm{BIm}\right), 136.82\left(\mathrm{C}^{\mathrm{q}} \mathrm{CH}_{3} \mathrm{C} \mathrm{BIm}\right)$, $135.28\left(\mathrm{~d}, J_{\mathrm{CP}}=7.5 \mathrm{~Hz}, \mathrm{C}^{\mathrm{q}} \mathrm{PPh}_{2}\right), 134.62\left(\mathrm{~d}, J_{\mathrm{CP}}=20 \mathrm{~Hz}, \mathrm{CH} \mathrm{PPh}_{2}\right)$, $131.81\left(\mathrm{~d}, J_{\mathrm{CP}}=19 \mathrm{~Hz}, \mathrm{CH} \mathrm{PPh}_{2}\right), 130.93\left(\mathrm{C}^{\mathrm{q}} \mathrm{BIm}\right), 129.94\left(\mathrm{C}^{\mathrm{q}}\right.$ BIm), $129.55(\mathrm{CH} \mathrm{PPh} 2), 128.38$ (d, $\left.J_{\mathrm{CP}}=8 \mathrm{~Hz}, \mathrm{CH} \mathrm{PPh}_{2}\right), 127.88$ $(\mathrm{CH} \mathrm{PPh} 2), 127.65$ (d, J $\left.J_{\mathrm{CP}}=6.5 \mathrm{~Hz}, \mathrm{CH} \mathrm{PPh}\right), 113.11(\mathrm{CH} \mathrm{BIm})$, ${ }_{35} 111.89(\mathrm{CH} \mathrm{BIm}), 83.97\left(\mathrm{C}^{\mathrm{q}} \mathrm{Cp}_{\mathrm{A}}\right), 77.21\left(\mathrm{C}^{\mathrm{q}} \mathrm{Cp}_{\mathrm{A}}\right), 74.30(\mathrm{CH}$ $\left.\left.\mathrm{Cp}_{\mathrm{A}}\right), 72.94\left(\mathrm{CH} \mathrm{Cp} \mathrm{p}_{\mathrm{A}}\right), 71.06\left(\mathrm{CH} \mathrm{Cp}_{\mathrm{A}}\right), 70.30(\mathrm{CH} \mathrm{Cp})_{\mathrm{B}}\right), 46.26(\mathrm{~d}$, $\left.J_{\mathrm{CP}}=9 \mathrm{~Hz}, \mathrm{CH}_{2}-\mathrm{Fc}\right), 32.93\left(\mathrm{CH}_{3}-\mathrm{N}\right), 20.61+20.47\left(\mathrm{CH}_{3} \mathrm{BIm}\right)$. ${ }^{31} \mathrm{P}\left\{{ }^{1} \mathrm{H}\right\} \mathrm{NMR}\left(121.5 \mathrm{MHz}, \mathrm{CDCl}_{3}, 298 \mathrm{~K}\right) \delta-26.43$. MS (ESI) $\mathrm{m} / \mathrm{z}$ $543\left[\mathrm{M}^{+}\right](100), 575\left[\mathrm{M}^{+}+\mathrm{S}\right](70), 383\left[\mathrm{M}^{+}-\mathrm{C}_{10} \mathrm{H}_{12} \mathrm{~N}_{2}\right](65)$. $40 \mathrm{HRMS}\left(\mathrm{ES}^{+}\right)$calcd for $\mathrm{C}_{33} \mathrm{H}_{32} \mathrm{~N}_{2} \mathrm{PFe} 543.1699$; found 543.1662 . (S)-3c: $[\alpha]^{20} \mathrm{D}^{=}=-201\left(\mathrm{c}=0.55, \mathrm{CH}_{2} \mathrm{Cl}_{2}\right)$.

FcPPh $_{2} \mathbf{C H}_{2} \mathbf{B I m}^{+ \text {CH}_{2} M e s} \mathbf{B F}_{4}^{-}$3d: yellow solid (500 mg, 82\% yield). ${ }^{1} \mathrm{H}$ NMR $\left(500 \mathrm{MHz}, \mathrm{CDCl}_{3}, 301 \mathrm{~K}\right) \delta 8.90(1 \mathrm{H}, \mathrm{s}, \mathrm{NCHN})$, 7.50-7.47 (3H, m, CH BIm+PPh2), 7.44-7.38 (3H, m, CH PPh $)$, ${ }_{45} 6.98\left(1 \mathrm{H}, \mathrm{t}, J_{\mathrm{HH}}=7.5 \mathrm{~Hz}, \mathrm{CH} \mathrm{PPh}_{2}\right), 6.94(2 \mathrm{H}, \mathrm{s}, \mathrm{CH} \mathrm{Mes}), 6.81$ $\left(2 \mathrm{H}, \mathrm{t}, J_{\mathrm{HH}}=7.5 \mathrm{~Hz}, \mathrm{CH} \mathrm{PPh}_{2}\right), 6.79(1 \mathrm{H}, \mathrm{s}, \mathrm{CH} \mathrm{BIm}), 6.63-6.60$ $\left(2 \mathrm{H}, \mathrm{m}, \mathrm{CH} \mathrm{PPh}_{2}\right), 5.78\left(1 \mathrm{H}, \mathrm{dd}, \mathrm{JHH}_{\mathrm{HH}}=14.9 \mathrm{~Hz}, J_{\mathrm{PH}}=1.8 \mathrm{~Hz}, \mathrm{CH}_{2}-\right.$ Fc), $5.57\left(1 \mathrm{H}, \mathrm{AB}\right.$ syst., $\left.J_{\mathrm{HH}}=14.9 \mathrm{~Hz}, \mathrm{CH}_{2}-\mathrm{Fc}\right), 5.33(1 \mathrm{H}, \mathrm{AB}$ syst., $\left.J_{\mathrm{HH}}=14.7 \mathrm{~Hz}, \mathrm{CH}_{2}-\mathrm{Mes}\right), 5.26\left(1 \mathrm{H}, \mathrm{AB}\right.$ syst., $J_{\mathrm{HH}}=14.6 \mathrm{~Hz}, \mathrm{CH}_{2}-$ $50 \mathrm{Mes}), 5.08\left(1 \mathrm{H}\right.$, br. s, $\mathrm{CH} \mathrm{Cp}$ ) $, 4.49\left(1 \mathrm{H}\right.$, br. s, CH Cp $\left.\mathrm{A}_{\mathrm{A}}\right), 4.13(5 \mathrm{H}$, s, CH Cpв), $3.88\left(1 \mathrm{H}\right.$, br. s, CH Cp $\left.\mathrm{p}_{\mathrm{A}}\right), 2.33\left(3 \mathrm{H}, \mathrm{s}, p-\mathrm{CH}_{3} \mathrm{Mes}\right)$, $2.23\left(6 \mathrm{H}, \mathrm{s}, \mathrm{CH}_{3} \mathrm{BIm}\right), 2.17\left(6 \mathrm{H}, \mathrm{s}, o-\mathrm{CH}_{3} \mathrm{Mes}\right) .{ }^{13} \mathrm{C}\left\{{ }^{1} \mathrm{H}\right\} \mathrm{NMR}$ $\left(125.8 \mathrm{MHz}, \mathrm{CDCl}_{3}, 301 \mathrm{~K}\right) \delta 139.88\left(\mathrm{C}^{\mathrm{q}} p-\mathrm{CH}_{3} \mathrm{CMes}\right), 139.83(\mathrm{~d}$, $\left.J_{\mathrm{CP}}=1.8 \mathrm{~Hz}, \mathrm{NCHN}\right), 139.11\left(\mathrm{~d}, J_{\mathrm{CP}}=8 \mathrm{~Hz}, \mathrm{C}^{\mathrm{q}} \mathrm{PPh}_{2}\right), 138.00\left(\mathrm{C}^{\mathrm{q}} o-\right.$ $\left.{ }_{55} \mathrm{CH}_{3} C \mathrm{Mes}\right), 136.81\left(\mathrm{C}^{\mathrm{q}} \mathrm{CH}_{3} C \mathrm{BIm}\right), 136.10$ (d, $J_{\mathrm{CP}}=6 \mathrm{~Hz}, \mathrm{C}^{\mathrm{q}} \mathrm{PPh}_{2}$ ), $135.02\left(\mathrm{~d}, J_{\mathrm{CP}}=21 \mathrm{~Hz}, o-C \mathrm{H} \mathrm{PPh}\right), 131.28\left(\mathrm{~d}, J_{\mathrm{CP}}=18 \mathrm{~Hz}, o-C \mathrm{H}\right.$ $\mathrm{PPh}_{2}$ ), 130.04 (CH Mes), 129.70 (d, $\left.p-C H \mathrm{PPh}_{2}\right), 129.68$ (C $\left.\mathrm{C}^{\mathrm{q}} \mathrm{BIm}\right)$, 129.45 (d, $p$-CH PPh $), 128.34$ (d, $\left.J_{\mathrm{CP}}=8 \mathrm{~Hz}, m-C H \mathrm{PPh}_{2}\right), 127.58$ (d, $\left.J_{\mathrm{CP}}=6 \mathrm{~Hz}, m-C \mathrm{H} \mathrm{PPh}_{2}\right), 127.48\left(\mathrm{C}^{\mathrm{q}} \mathrm{BIm}\right), 124.65\left(\mathrm{C}^{\mathrm{q}} \mathrm{NCH}_{2} \mathrm{C}\right.$ $\left.{ }_{60} \mathrm{Mes}\right), 113.62$ (d, $\left.J_{\mathrm{CP}}=5 \mathrm{~Hz}, \mathrm{CH} \mathrm{BIm}\right), 112.46$ (CH BIm), 85.17 (d, $\left.J_{\mathrm{CP}}=28 \mathrm{~Hz}, \mathrm{C}^{\mathrm{q}} \mathrm{Cp}_{\mathrm{A}}\right), 76.21\left(\mathrm{~d}, J_{\mathrm{CP}}=9 \mathrm{~Hz}, \mathrm{C}^{\mathrm{q}} \mathrm{Cp}_{\mathrm{A}}\right), 73.82\left(\mathrm{~d}, J_{\mathrm{CP}}=3.7\right.$ $\left.\mathrm{Hz}, \mathrm{CH} \mathrm{Cp} \mathrm{p}_{\mathrm{A}}\right), 72.79$ (d, $\left.J_{\mathrm{CP}}=4.5 \mathrm{~Hz}, \mathrm{CH} \mathrm{Cp} \mathrm{p}_{\mathrm{A}}\right), 71.39\left(\mathrm{CH} \mathrm{Cp} \mathrm{p}_{\mathrm{A}}\right)$, 70.35 (CH Срв), 46.53 (dd, $\left.J_{\mathrm{CP}}=9.6 \mathrm{~Hz}, \mathrm{CH}_{2}-\mathrm{Fc}\right), 46.28$ (d, $\mathrm{CH}_{2}-$ Mes), 21.07 ( $\left.p-\mathrm{CH}_{3} \mathrm{Mes}\right), 20.59+20.46\left(\mathrm{CH}_{3} \mathrm{BIm}\right), 19.75\left(o-\mathrm{CH}_{3}\right.$ $\left.{ }_{65} \mathrm{Mes}\right) .{ }^{31} \mathrm{P}\left\{{ }^{1} \mathrm{H}\right\}$ NMR $\left(202.5 \mathrm{MHz}, \mathrm{CDCl}_{3}, 301 \mathrm{~K}\right) \delta-25.68$. MS (ESI) m/z $677\left[\mathrm{M}^{+}+\mathrm{O}\right](10), 661\left[\mathrm{M}^{+}\right](100), 383\left[\mathrm{M}^{+}-\mathrm{C}_{19} \mathrm{H}_{22} \mathrm{~N}_{2}\right]$ (10). HRMS $\left(\mathrm{ES}^{+}\right)$calcd for $\mathrm{C}_{42} \mathrm{H}_{42} \mathrm{~N}_{2} \mathrm{PFe}$ 661.2435; found 661.2443. (S)-3d: $[\alpha]^{20} \mathrm{D}=-224\left(\mathrm{c}=0.55, \mathrm{CH}_{2} \mathrm{Cl}_{2}\right)$.

General procedure for the synthesis of $\operatorname{PdCl}_{2}[\mathrm{~L}]$ complexes $\underline{4 b-}$ $70 \underline{\mathbf{d}}$

A mixture of $\mathrm{PdCl}_{2}\left(\mathrm{PhCN}_{2}\right.$ (1 equiv), $\mathrm{FcPPh}_{2} \mathrm{CH}_{2} \mathrm{Im} / \mathrm{BIm}^{+\mathrm{R}} \mathrm{BF}_{4}^{-}$ 3b-d (50 mg, 1 equiv.) and $\mathrm{NaO} t \mathrm{Bu}$ (1.1 equiv) in dry $\mathrm{CH}_{3} \mathrm{CN}$ (50 $\mathrm{mL}$ ) was heated at $50^{\circ} \mathrm{C}$ for $16 \mathrm{~h}$. The solution was allowed to cool to room temperature, concentrated in vacuo and the residue was 75 purified by flash chromatography on silica gel (eluent : $\mathrm{CH}_{2} \mathrm{Cl}_{2} / \mathrm{MeOH}$ 9/1).

$\underline{\mathbf{4 b}}$ : orange solid (35 mg, 61\% yield). X-ray quality crystals of (S)$\mathbf{4 b}$ were obtained by slow diffusion of petroleum ether in a solution of dichloromethane. ${ }^{1} \mathrm{H}$ NMR $\left(500 \mathrm{MHz}, \mathrm{CDCl}_{3}, 298 \mathrm{~K}\right) \delta 7.92$ ${ }_{80}(2 \mathrm{H}, \mathrm{m}, \mathrm{CH} \mathrm{PPh} 2), 7.51(1 \mathrm{H}, \mathrm{m}, \mathrm{CH} \mathrm{PPh}), 7.44(2 \mathrm{H}, \mathrm{m}, \mathrm{CH} \mathrm{PPh})$, $7.41(1 \mathrm{H}, \mathrm{m}, \mathrm{CH} \mathrm{PPh} 2), 7.32(2 \mathrm{H}, \mathrm{m}, \mathrm{CH} \mathrm{PPh}), 7.18(2 \mathrm{H}, \mathrm{m}, \mathrm{CH}$ $\left.\mathrm{PPh}_{2}\right), 6.79(1 \mathrm{H}, \mathrm{s}, \mathrm{NCH}=\mathrm{CH}), 6.78(2 \mathrm{H}, \mathrm{s}, \mathrm{CH} \mathrm{Mes}), 6.54(1 \mathrm{H}, \mathrm{AB}$ syst., $\left.J_{\mathrm{HH}}=15 \mathrm{~Hz}, \mathrm{CH}_{2}-\mathrm{Fc}\right), 5.97(1 \mathrm{H}, \mathrm{s}, \mathrm{NCH}=\mathrm{CH}), 5.94(1 \mathrm{H}, \mathrm{AB}$ syst., $\left.J_{\mathrm{HH}}=15 \mathrm{~Hz}, \mathrm{CH}_{2}-\mathrm{Mes}\right), 4.75\left(1 \mathrm{H}, \mathrm{AB}\right.$ syst., $J_{\mathrm{HH}}=15 \mathrm{~Hz}, \mathrm{CH}_{2}-$ $\left.{ }_{85} \mathrm{Fc}\right), 4.74(1 \mathrm{H}$, br s, $\mathrm{CH} \mathrm{Cp}$ ), $4.42(1 \mathrm{H}$, br s, $\mathrm{CH} \mathrm{Cp}$ ), $4.28(5 \mathrm{H}$, s, $\left.\mathrm{CH} \mathrm{Cp}_{\mathrm{B}}\right), 4.00\left(1 \mathrm{H}, \mathrm{AB}\right.$ syst., $\left.J_{\mathrm{HH}}=15 \mathrm{~Hz}, \mathrm{CH}_{2}-\mathrm{Mes}\right), 3.70(1 \mathrm{H}$, br s, $\mathrm{CH} \mathrm{Cp}$ ), 2.24 (3H, s, $\left.p-\mathrm{CH}_{3} \mathrm{Mes}\right), 1.91$ (6H, s, o- $\left.\mathrm{CH}_{3} \mathrm{Mes}\right)$. ${ }^{13} \mathrm{C}\left\{{ }^{1} \mathrm{H}\right\} \mathrm{NMR}\left(125.8 \mathrm{MHz}, \mathrm{CDCl}_{3}, 298 \mathrm{~K}\right) \delta 156 \mathrm{ppm}\left(\mathrm{C}^{\mathrm{q}} \mathrm{NCN}-\right.$ Pd, determined by HMBC), 139.03 (2 $\mathrm{C}^{q} \mathrm{Mes}, \mathrm{C}-\mathrm{o}-\mathrm{CH}_{3}$ ), 138.72 $90\left(\mathrm{C}^{\mathrm{q}} \mathrm{Mes}, C-p-\mathrm{CH}_{3}\right), 135.75\left(\mathrm{~d}, J_{\mathrm{CP}}=10 \mathrm{~Hz}, \mathrm{CH} \mathrm{PPh}_{2}\right), 134.46$ (d, $\left.J_{\mathrm{CP}}=54 \mathrm{~Hz}, \mathrm{C}^{\mathrm{q}} \mathrm{PPh}_{2}\right), 131.33\left(\mathrm{~d}, J_{\mathrm{CP}}=11 \mathrm{~Hz}, \mathrm{CH} \mathrm{PPh}\right), 131.16(\mathrm{CH}$ $\left.\mathrm{PPh}_{2}\right), 130.68\left(\mathrm{CH} \mathrm{PPh}_{2}\right), 129.18(\mathrm{CH} \mathrm{Mes}), 128.86\left(\mathrm{~d}, J_{\mathrm{CP}}=54 \mathrm{~Hz}\right.$, $\left.\mathrm{C}^{\mathrm{q}} \mathrm{PPh}_{2}\right), 128.71\left(\mathrm{~d}, J_{\mathrm{CP}}=11 \mathrm{~Hz}, \mathrm{CH} \mathrm{PPh}\right), 127.39$ (d, $J_{\mathrm{CP}}=11 \mathrm{~Hz}$, $\left.\mathrm{CH} \mathrm{PPh}_{2}\right), 126.78\left(\mathrm{C}^{\mathrm{q}} \mathrm{Mes}, C-\mathrm{CH}_{2}\right), 121.00(\mathrm{NCH}=\mathrm{CH}), 119.00$ ${ }_{95}(\mathrm{NCH}=\mathrm{CH}), 86.99\left(\mathrm{~d}, J_{\mathrm{CP}}=14 \mathrm{~Hz}, \mathrm{C}^{\mathrm{q}} \mathrm{Cp}_{\mathrm{A}}\right), 74.85\left(\mathrm{CH} \mathrm{Cp} \mathrm{C}_{\mathrm{A}}\right), 72.90$ $\left(\mathrm{d}, J_{\mathrm{CP}}=56 \mathrm{~Hz}, \mathrm{CH} \mathrm{Cp} \mathrm{p}_{\mathrm{A}}\right), 71.83\left(\mathrm{~d}, J_{\mathrm{CP}}=58 \mathrm{~Hz}, \mathrm{C}^{\mathrm{q}} \mathrm{Cp}_{\mathrm{A}}\right), 71.43(5$ $\mathrm{CH}$ Срв), 70.13 ( $\mathrm{CH} \mathrm{Cp}$ ), 50.08 ( $\left.\mathrm{CH}_{2}-\mathrm{Fc}\right), 48.03$ ( $\left.\mathrm{CH}_{2}-\mathrm{Mes}\right)$, $20.92\left(p-\mathrm{CH}_{3} \mathrm{Mes}\right), 20.60\left(o-\mathrm{CH}_{3} \mathrm{Mes}\right) .{ }^{31} \mathrm{P}\left\{{ }^{1} \mathrm{H}\right\}$ NMR $(202.5$ $\left.\mathrm{MHz}, \mathrm{CDCl}_{3}, 298 \mathrm{~K}\right) \delta 4.56$. MS (ESI) $\mathrm{m} / \mathrm{z} 723\left[{\left.\mathrm{M}-\mathrm{Cl}^{-}\right]}(100)\right.$, $100242\left[\mathrm{PdCl}_{2} \mathrm{Im}\right](80)$. HRMS $\left(\mathrm{ES}^{+}\right)$calcd for $\mathrm{C}_{36} \mathrm{H}_{35} \mathrm{~N}_{2} \mathrm{PFePdCl}$ 723.0623; found 723.0652. (S)-4b : $[\alpha]^{20}{ }_{\mathrm{D}}=-5\left(\mathrm{c}=0.5, \mathrm{CH}_{2} \mathrm{Cl}_{2}\right)$.

4c: orange solid (30 mg, $54 \%$ yield). X-ray quality crystals of $(S)$ 4c were obtained by slow diffusion of acetone in a solution of dichloromethane. ${ }^{1} \mathrm{H} \mathrm{NMR}\left(500 \mathrm{MHz}, \mathrm{CD}_{2} \mathrm{Cl}_{2}, 298 \mathrm{~K}\right) \delta 8.08(2 \mathrm{H}$, $\left.{ }_{105} \mathrm{~m}, \mathrm{CH} o-\mathrm{PPh}_{2}\right), 7.61\left(1 \mathrm{H}, \mathrm{m}, \mathrm{CH} p-\mathrm{PPh}_{2}\right), 7.52(2 \mathrm{H}, \mathrm{m}, \mathrm{CH} m-$ $\left.\mathrm{PPh}_{2}\right), 7.28\left(1 \mathrm{H}, \mathrm{m}, \mathrm{CH} p-\mathrm{PPh}_{2}\right), 7.20(1 \mathrm{H}, \mathrm{s}, \mathrm{CH} \mathrm{BIm}), 7.06(2 \mathrm{H}$, $\left.\mathrm{m}, \mathrm{CH} o-\mathrm{PPh}_{2}\right), 6.83(1 \mathrm{H}, \mathrm{s}, \mathrm{CH} \mathrm{BIm}), 6.76\left(2 \mathrm{H}, \mathrm{m}, \mathrm{CH} m-\mathrm{PPh}_{2}\right)$, $6.64\left(1 \mathrm{H}, \mathrm{AB}\right.$ syst., $\left.J_{\mathrm{HH}}=15 \mathrm{~Hz}, \mathrm{CH}_{2}-\mathrm{Fc}\right), 5.21(1 \mathrm{H}, \mathrm{AB}$ syst., $\left.J_{\mathrm{HH}}=15 \mathrm{~Hz}, \mathrm{CH}_{2}-\mathrm{Fc}\right), 4.94(1 \mathrm{H}$, br s, CH CpA $), 4.43(1 \mathrm{H}$, br s, $\mathrm{CH}$ $\left.{ }_{10} \mathrm{Cp}_{\mathrm{A}}\right), 4.42(1 \mathrm{H}$, br s, $\mathrm{CH} \mathrm{Cp}), 3.62\left(3 \mathrm{H}, \mathrm{s}, \mathrm{N}-\mathrm{CH}_{3}\right), 2.38(3 \mathrm{H}, \mathrm{s}$, $\mathrm{CH}_{3}$-BIm), $2.32\left(3 \mathrm{H}, \mathrm{s}, \mathrm{CH}_{3}-\mathrm{BIm}\right) .{ }^{13} \mathrm{C}\left\{{ }^{1} \mathrm{H}\right\}$ NMR $(125.8 \mathrm{MHz}$, $\left.\mathrm{CD}_{2} \mathrm{Cl}_{2}, 298 \mathrm{~K}\right) \delta 166.70$ (Cq NCN-Pd), $136.02\left(\mathrm{~d}, J_{\mathrm{CP}}=10 \mathrm{~Hz}, o-\right.$ $\mathrm{CH} \mathrm{PPh}$ ), 134.31 (d, $\left.J_{\mathrm{CP}}=55 \mathrm{~Hz}, \mathrm{C}^{\mathrm{q}} \mathrm{PPh}_{2}\right), 133.49\left(\mathrm{C}^{\mathrm{q}} \mathrm{BIm}\right)$, 133.10 ( $\left.2 \mathrm{Cq}^{\mathrm{q}} \mathrm{CH}_{3}-\mathrm{C} \mathrm{BIm}\right), 131.40$ (d, $J_{\mathrm{CP}}=2.5 \mathrm{~Hz}, p-\mathrm{CH} \mathrm{PPh}_{2}$ ), $115130.90\left(\mathrm{C}^{\mathrm{q}} \mathrm{BIm}\right), 130.65$ (d, $\left.J_{\mathrm{CP}}=11 \mathrm{~Hz}, o-\mathrm{CH} \mathrm{PPh}_{2}\right), 130.00$ (d, $\left.J_{\mathrm{CP}}=2.5 \mathrm{~Hz}, p-\mathrm{CH} \mathrm{PPh}_{2}\right), 128.34\left(\mathrm{~d}, J_{\mathrm{CP}}=10 \mathrm{~Hz}, m-\mathrm{CH} \mathrm{PPh}_{2}\right)$, $127.58\left(\mathrm{~d}, J_{\mathrm{CP}}=54 \mathrm{~Hz}, \mathrm{C}^{\mathrm{q}} \mathrm{PPh}_{2}\right), 127.48\left(\mathrm{~d}, J_{\mathrm{CP}}=11 \mathrm{~Hz}, m-\mathrm{CH}\right.$ 
$\left.\mathrm{PPh}_{2}\right), 110.45$ (CH BIm), 109.71 (CH BIm), 86.80 (d, J $J_{\mathrm{CP}}=14 \mathrm{~Hz}$, $\left.\mathrm{C}^{\mathrm{q}} \mathrm{Cp}_{\mathrm{A}}\right), 74.23\left(\mathrm{~d}, J_{\mathrm{CP}}=2.5 \mathrm{~Hz}, \mathrm{CH} \mathrm{Cp}_{\mathrm{A}}\right), 73.51\left(\mathrm{~d}, J_{\mathrm{CP}}=8 \mathrm{~Hz}, \mathrm{CH}\right.$ $\left.\mathrm{Cp}_{\mathrm{A}}\right), 71.36\left(5 \mathrm{CH} \mathrm{Cp}_{\mathrm{B}}\right), 71.00\left(\mathrm{~d}, J_{\mathrm{CP}}=58 \mathrm{~Hz}, \mathrm{C}^{\mathrm{q}} \mathrm{Cp}_{\mathrm{A}}\right), 70.39(\mathrm{~d}$,

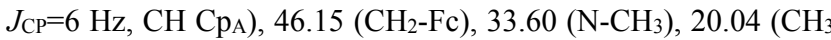
$\left.{ }_{5} \mathrm{BIm}\right), 19.95\left(\mathrm{CH}_{3} \mathrm{BIm}\right) .{ }^{31} \mathrm{P}\left\{{ }^{1} \mathrm{H}\right\} \mathrm{NMR}\left(202.5 \mathrm{MHz}, \mathrm{CD}_{2} \mathrm{Cl}_{2}, 298\right.$ K) $\delta 4.38$. MS (ESI) m/z $683\left[\mathrm{M} \mathrm{-} \mathrm{Cl}^{-}\right](100), 647\left[\mathrm{M}-2 \mathrm{Cl}^{-}\right]$(33). HRMS $\left(\mathrm{ES}^{+}\right)$calcd for $\mathrm{C}_{33} \mathrm{H}_{31} \mathrm{~N}_{2} \mathrm{PFePdCl}$ 683.0309; found 683.0313. $(S)-4 \mathrm{c}:[\alpha]^{20}{ }_{\mathrm{D}}=-59\left(\mathrm{c}=0.54, \mathrm{CH}_{2} \mathrm{Cl}_{2}\right)$.

4d: yellow solid (20 mg, 35\% yield). X-ray quality crystals of rac-

10 4d were obtained by slow diffusion of diethyl ether in a solution of dichloromethane. ${ }^{1} \mathrm{H}$ NMR $\left(500 \mathrm{MHz}, \mathrm{CDCl}_{3}, 298 \mathrm{~K}\right) \delta 8.00(2 \mathrm{H}$, $\mathrm{m}, \mathrm{CH} \mathrm{PPh} 2), 7.52-7.46$ (2H, m, CH PPh $), 7.31-7.29(2 \mathrm{H}, \mathrm{m}, \mathrm{CH}$ $\mathrm{PPh}_{2}$ ), 7.12 (1H, m, CH BIm), 6.96-6.94 (2H, m, CH PPh2), 6.77 $(2 \mathrm{H}, \mathrm{s}, \mathrm{CH} \mathrm{PPh}), 6.78(2 \mathrm{H}, 2 \mathrm{~s}, \mathrm{CH} \mathrm{Mes}), 6.77(1 \mathrm{H}, \mathrm{AB}$ syst., $\left.{ }_{15} J_{\mathrm{HH}}=15 \mathrm{~Hz}, \mathrm{Fc}-\mathrm{CH}_{2}\right), 6.28\left(1 \mathrm{H}, \mathrm{AB}\right.$ syst., $\left.J_{\mathrm{HH}}=15 \mathrm{~Hz}, \mathrm{CH}_{2}-\mathrm{Mes}\right)$, $5.41(1 \mathrm{H}, \mathrm{s}, \mathrm{CH} \mathrm{BIm}), 5.14\left(1 \mathrm{H}, \mathrm{AB}\right.$ syst., $\left.J_{\mathrm{HH}}=15 \mathrm{~Hz}, \mathrm{Fc}-\mathrm{CH}_{2}\right)$, $4.85(1 \mathrm{H}$, br. $\mathrm{s}, \mathrm{Cp} \mathrm{A}), 4.40\left(1 \mathrm{H}\right.$, br. $\left.\mathrm{s}, \mathrm{Cp}_{\mathrm{A}}\right), 4.32(5 \mathrm{H}, \mathrm{s}, \mathrm{Cp}), 4.31$ $\left(1 \mathrm{H}, \mathrm{AB}\right.$ syst., $\left.J_{\mathrm{HH}}=15 \mathrm{~Hz}, \mathrm{CH}_{2}-\mathrm{Mes}\right), 3.65\left(1 \mathrm{H}\right.$, br. $\left.\mathrm{s}, \mathrm{Cp}_{\mathrm{A}}\right), 2.29$ $\left(6 \mathrm{H}, \mathrm{s}, \mathrm{CH}_{3} \mathrm{BIm}\right), 1.95\left(6 \mathrm{H}, \mathrm{s}, o-\mathrm{CH}_{3} \mathrm{Mes}\right), 1.91\left(3 \mathrm{H}, \mathrm{s}, p-\mathrm{CH}_{3}\right.$ $\left.{ }^{20} \mathrm{Mes}\right) .{ }^{13} \mathrm{C}\left\{{ }^{1} \mathrm{H}\right\}$ NMR $\left(125.8 \mathrm{MHz}, \mathrm{CDCl}_{3}, 298 \mathrm{~K}\right) \delta 166.74\left(\mathrm{C}^{\mathrm{q}}\right.$ NCN-Pd), 138.47 (Cq BIm), 135.93 (d, $\left.J_{\mathrm{CP}}=10 \mathrm{~Hz}, o-\mathrm{CH} \mathrm{PPh}_{2}\right)$, $134.19\left(\mathrm{~d}, J_{\mathrm{CP}}=54 \mathrm{~Hz}, \mathrm{C}^{\mathrm{q}} \mathrm{PPh}_{2}\right), 133.49\left(\mathrm{C}^{\mathrm{q}} \mathrm{BIm}\right), 132.45\left(\mathrm{C}^{\mathrm{q}} \mathrm{CH}_{3-}\right.$ $C$ BIm), 132.34 ( $\left.\mathrm{C}^{\mathrm{q}} \mathrm{CH}_{3}-C \mathrm{BIm}\right), 131.47$ ( $\left.\mathrm{C}^{\mathrm{q}} \mathrm{Mes}, C-p-\mathrm{CH}_{3}\right)$, $131.18\left(\mathrm{C}^{\mathrm{q}} \mathrm{Mes}, C-o-\mathrm{CH}_{3}\right), 131.02\left(\mathrm{~d}, J_{\mathrm{CP}}=11 \mathrm{~Hz}, \mathrm{CH} \mathrm{PPh}_{2}\right), 129$. $2589\left(\mathrm{C}^{\mathrm{q}} \mathrm{Mes}, C-o-\mathrm{CH}_{3}\right), 129.10(\mathrm{CH} \mathrm{Mes}), 128.79$ (d, $J_{\mathrm{CP}}=55 \mathrm{~Hz}$, $\left.\mathrm{C}^{\mathrm{q}} \mathrm{PPh}_{2}\right), 127.43$ (d, $\left.J_{\mathrm{CP}}=11 \mathrm{~Hz}, \mathrm{CH} \mathrm{PPh}_{2}\right), 128.49$ (d, $J_{\mathrm{CP}}=10 \mathrm{~Hz}$, $\mathrm{CH} \mathrm{PPh}_{2}$ ), 126.84 (CH Mes), 112.45 (CH BIm), 109.23 (CH BIm), $86.52\left(\mathrm{~d}, J_{\mathrm{CP}}=14 \mathrm{~Hz}, \mathrm{C}^{\mathrm{q}} \mathrm{Cp}_{\mathrm{A}}\right), 74.42(\mathrm{CH} \mathrm{Cp}), 72.05\left(\mathrm{C}^{\mathrm{q}}, \mathrm{Cp}_{\mathrm{A}}\right)$, $72.93\left(\mathrm{~d}, J_{\mathrm{CP}}=1.5 \mathrm{~Hz}, \mathrm{CH} \mathrm{Cp}_{\mathrm{A}}\right), 71.39(5 \mathrm{CH}, \mathrm{CpB}), 70.16(\mathrm{~d}$, $\left.{ }_{30} J_{\mathrm{CP}}=1.5 \mathrm{~Hz}, \mathrm{CH} \mathrm{Cp} \mathrm{A}\right), 49.00\left(\mathrm{CH}_{2}-\mathrm{Mes}\right), 46.52\left(\mathrm{CH}_{2}-\mathrm{Fc}\right), 21.12(o-$ $\left.\mathrm{CH}_{3} \mathrm{Mes}\right), 20.92\left(\mathrm{CH}_{3} \mathrm{BIm}\right), 20.37$ (p- $\left.\mathrm{CH}_{3} \mathrm{Mes}\right), 20.26\left(\mathrm{CH}_{3}\right.$ BIm). ${ }^{31} \mathrm{P}\left\{{ }^{1} \mathrm{H}\right\}$ NMR $\left(202.5 \mathrm{MHz}, \mathrm{CDCl}_{3}, 298 \mathrm{~K}\right) \delta 3.86$. MS (DCI-CH4) m/z 801 [M - Cl] (100), 767 [M - 2Cl] (58). HRMS $(\mathrm{Cl}+)$ calcd for $\mathrm{C}_{42} \mathrm{H}_{41} \mathrm{~N}_{2} \mathrm{PFePdCl} 801.1080$; found 801.1118. (S)${ }_{35}$ 4d: $[\alpha]^{20}{ }_{D}=-32\left(\mathrm{c}=0.51, \mathrm{CH}_{2} \mathrm{Cl}_{2}\right)$.

General procedure for Suzuki-Miyaura coupling reactions: in a typical run, a mixture of naphthyl halide ( $0.29 \mathrm{mmol}, 1$ equiv), naphthylboronic acid ( $0.34 \mathrm{mmol}, 1.2$ equiv), potassium carbonate ( $0.69 \mathrm{mmol}, 2.4$ equiv) and catalyst $(0.5 \mathrm{~mol} \%)$ in $2 \mathrm{~mL}$ of toluene $40\left(+50 \mu \mathrm{L}\right.$ of $\mathrm{CH}_{2} \mathrm{Cl}_{2}$ for complete solubilisation) was stirred for $24 \mathrm{~h}$ at $40^{\circ} \mathrm{C}$. The solution was allowed to cool to room temperature, washed with water and the aqueous phase was extracted with diethyl ether. The organic phase was dried over $\mathrm{MgSO}_{4}$, filtered and concentrated in vacuo. The residue was purified by flash 45 chromatography on silica gel (hexane or hexane/ethyl acetate 9/1). Enantiomeric excesses were determined by HPLC with a Chiralcel OJ column (eluent: Hexane/iPrOH 9/1, rate: $1 \mathrm{~mL} / \mathrm{min}, \mathrm{T}=30^{\circ} \mathrm{C}$ ). Retention time for 2-methylbinaphthyl: $6.42 \mathrm{~min}$ ( $R$ isomer $)-9.93$ $\min (S$ isomer). Retention time for 2-methoxybinaphthyl: $9.22 \mathrm{~min}$ ${ }_{50}(S$ isomer $)$ - $15.66 \mathrm{~min}$ ( $R$ isomer $)$. Retention time for 2ethoxybinaphthyl: $7.66 \mathrm{~min}$ ( $S$ isomer $)-11.90 \mathrm{~min}(R$ isomer $)$.

General procedure for 1,2-addition reactions: A mixture of 4nitrobenzaldehyde $(0.2 \mathrm{mmol}, 1$ equiv), phenylboronic acid $(0.4$ mmol, 2 equiv (THF) or $0.3 \mathrm{mmol}, 1.5$ equiv (other solvents)), base

${ }_{55}$ ( $0.6 \mathrm{mmol}, 3$ equiv (THF) or $0.4 \mathrm{mmol} 2$ equiv (other solvents)) and catalyst ( $5 \mathrm{~mol} \%$ ) in a solvent (THF: $5 \mathrm{~mL}$, other solvents: 1 $\mathrm{mL}$ ) was stirred for $24 \mathrm{~h}$ at $65^{\circ} \mathrm{C}$. After cooling to room temperature, water was added and the aqueous phase was extracted with $t \mathrm{BuOMe}$. The organic phases were washed with brine, dried $60\left(\mathrm{MgSO}_{4}\right)$, filtered and concentrated in vacuo. After analysis by ${ }^{1} \mathrm{H}$ NMR ( $d_{6}$-acetone), the residue was purified by flash chromatography on silica gel (petroleum ether/EtOAc 8/1 then 4/1) to give pure (4-nitrophenyl)(phenyl)methanol as a yellow solid. It was analysed by chiral HPLC using a Chiracel AD-H column, ${ }_{65}$ (hexane $/ 2$-propanol $=80: 20$, flow rate $=0.5 \mathrm{~mL} / \mathrm{min}$, wavelength $=214 \mathrm{~nm}, 13.9 \mathrm{~min}$ ( $R$ isomer $)$ and $16.4 \mathrm{~min}(S$ isomer $)$.

\section{$\mathrm{X}$-ray structural analyses.}

Single crystal of each compound was mounted under inert perfluoropolyether at the tip of glass fiber and cooled in the 70 cryostream of either an Oxford-Diffraction XCALIBUR CCD diffractometer for $r a c-2 c$ and $(S)-\mathbf{4 c}$, a Bruker APEXII diffractometer for $\mathrm{rac}-\mathbf{2 d}$ and $(S)-\mathbf{4 b}$ or an Agilent Technologies GEMINI EOS diffractometer for $r a c-4 d$.

The structures were solved by direct methods (SIR97 ${ }^{28}$ ) and 75 refined by least-squares procedures on $F^{2}$ using SHELXL-97. ${ }^{29}$ All $\mathrm{H}$ atoms attached to carbon were introduced in calculation in idealised positions and treated as riding models. In four of the five compounds, rac-2d, $(S)-\mathbf{4 b},(S)-\mathbf{4 c}$ and rac-4d, it was difficult to locate some disordered solvents, and the SQUEEZE option from ${ }_{80}$ PLATON ${ }^{30}$ has been used. The absolute configuration for compounds $(S)-\mathbf{4 b}$ and $(S)-\mathbf{4} \mathbf{c}$ has been determined by refining the Flack's parameter. ${ }^{31}$ The drawing of the molecules was realised with the help of ORTEP32. ${ }^{32}$

Crystallographic data (excluding structure factors) have been 85 deposited with the Cambridge Crystallographic Data Centre as supplementary publication no. CCDC 940117-940121. Copies of the data can be obtained free of charge on application to the Director, CCDC, 12 Union Road, Cambridge CB2 1EZ, UK (fax: (+44) 1223-336-033; e-mail: deposit@ccdc.cam.ac.uk).

\section{${ }_{90}$ Notes and references}

${ }^{a}$ CNRS, LCC (Laboratoire de Chimie de Coordination), 205 route de Narbonne, BP 44099, F-31077 Toulouse Cedex 4, France. Fax: (+33) 561553003; Tel: (+33) 561333158; E-mail: agnes.labande@lcc-toulouse.fr

$95{ }^{b}$ Université de Toulouse, UPS, INPT, F-31077 Toulouse Cedex 4, France.

${ }^{c}$ Department of Chemistry, Ege University, 35100 Bornova-Izmir, Turkey.

${ }^{d}$ Institut Universitaire de France, 103 bd Saint-Michel, F-75005 Paris, 100 France.

$\dagger$ Electronic Supplementary Information (ESI) available: ORTEP representations of compounds $2 \mathbf{2 a}$ and $\mathbf{4 a}$; crystal data and refinement parameters for 2c-d and 4b-d. See DOI: 10.1039/b000000x/

+ ORTEP representations of compounds $2 \mathbf{2 a}$ and $\mathbf{4 a}$ are given in the 105 Supplementary Information.

1 Selected reviews: H. M. Lee, C. C. Lee and P. Y. Cheng, Curr. Org. Chem., 2007, 11, 1491 ; O. Kuhl, Chem. Soc. Rev., 2007, 36, 592; A. T. Normand and K. J. Cavell, Eur. J. Inorg. Chem., 2008, 2781 ; A. John and P. Ghosh, Dalton Trans., 2010, 39, 7183.

102 NHC-P, selected papers: C. Yang, H. M. Lee and S. P. Nolan, Org. Lett., 2001, 3, 1511; N. Tsoureas, A. A. Danopoulos, A. A. D. Tulloch and M. E. Light, Organometallics, 2003, 22, 4750; H. Seo, H.-J. Park, B. Y. Kim, J. H. Lee, S. U. Son and Y. K. Chung, Organometallics, 2003, 22, 618; E. Bappert and G. Helmchen, Synlett, 2004, 1789; L. D. 115 Field, B. A. Messerle, K. Q. Vuong and P. Turner, Organometallics, 2005, 24, 4241; F. E. Hahn, M. C. Jahnke and T. Pape, Organometallics, 2006, 25, 5927; F. Visentin and A. Togni, Organometallics, 2007, 26, 3746; C.-C. Lee, W.-C. Ke, K.-T. Chan, C.-L. Lai, C.-H. Hu and H. M. Lee, Chem. Eur. J., 2007, 13, 582; C.C. Ho, S. Chatterjee, T.-L. Wu, K.-T. Chan, Y.-W. Chang, T.-H. Hsiao 
and H. M. Lee, Organometallics, 2009, 28, 2837; E. Kühnel, I. V. Shishkov, F. Rominger, T. Oeser and P. Hofmann, Organometallics, 2012, 31, 8000; S. Gaillard, J.-L. Renaud, Dalton Trans., 2013, 42, 7255.

53 M. Bierenstiel, E. D. Cross, Coord. Chem. Rev., 2011, 255, 574 and references therein ; C. Fliedel and P. Braunstein, Organometallics, 2010, 29, 5614 ; H. V. Huynh, D. Yuan and Y. Han, Dalton Trans., 2009, 7262 ; D. Krishnan, S. A. Pullarkat, M. Wu, Y. Li, and P.-H. Leung, Chem. Eur. J., 2013, 19, 5468; Y.-H. Chang, Z.-Y. Liu, Y.-H. Liu, S.-M. Peng, J.-T. Chen and S.-T. Liu, Dalton Trans., 2011, 40, 489; C. Lohre, T. Dröge, C. Wang and F. Glorius, Chem. Eur. J., 2011, 17, 6052; H. V. Huynh and Q. Teng, Chem. Commun., 2013, 49, 4244; Y.-C. Lin, H.-H. Hsueh, S. Kanne, L.-K. Chang, F.-C. Liu, I. J. B. Lin, G.-H. Lee and S.-M. Peng, Organometallics, 2013, 32, 3859.

154 J. Wolf, A. Labande, M. Natella, J.-C. Daran and R. Poli, J. Mol. Catal. A: Chem., 2006, 259, 205; J. Wolf, A. Labande, J.-C. Daran and R. Poli, Eur. J. Inorg. Chem., 2007, 5069 ; A. Labande, N. Debono, A. Sournia-Saquet, J.-C. Daran and R. Poli, Dalton Trans., 2013, 42, 6531.

205 A. Labande, J.-C. Daran, E. Manoury and R. Poli, Eur. J. Inorg. Chem., 2007, 1205.

6 S. Gülcemal, A. Labande, J.-C. Daran, B. Çetinkaya and R. Poli, Eur. J. Inorg. Chem., 2009, 1806.

7 N. Debono, A. Labande, E. Manoury, J.-C. Daran and R. Poli, Organometallics, 2010, 29, 1879.

8 S. Díez-González, N-Heterocyclic Carbenes : From Laboratory Curiosities to Efficient Synthetic Tools, RSC Publishing, Cambridge, UK, 2011; F. Glorius, N-Heterocyclic Carbenes in Transition Metal Catalysis, Springer-Verlag, Heidelberg, Germany, 2007; D.

30 Bourissou, O. Guerret, F. P. Gabbaï and G. Bertrand, Chem. Rev., 2000, 100, 39; F. E. Hahn and M. C. Jahnke, Angew. Chem. Int. Ed., 2008, 47, 3122; S. Díez-González, N. Marion and S. P. Nolan, Chem. Rev., 2009, 109, 3612; J. C. Y. Lin, R. T. W. Huang, C. S. Lee, A. Bhattacharyya, W. S. Hwang and I. J. B. Lin, Chem. Rev., 2009, 109, 3561; P. L. Arnold and I. J. Casely, Chem. Rev., 2009, 109, 3599; chiral NHCs : V. César, S. Bellemin-Laponnaz and L. H. Gade, Chem. Soc. Rev., 2004, 33, 619.

9 General reviews on Suzuki-Miyaura cross-coupling reaction: N Miyaura in Metal-Catalyzed Cross-Coupling Reactions, $2^{\text {nd }}$ Edition

40 (Eds: A. de Meijere, F. Diederich), Wiley-VCH, Weinheim, Germany, 2004, Ch. 2, pp. 41-123; N. Miyaura and A. Suzuki, Chem. Rev., 1995 95, 2457; G. A. Molander and B. Canturk, Angew. Chem. Int. Ed., 2009, 48, 9240; A. Suzuki, Angew. Chem. Int. Ed., 2011, 50, 6722; G. C. Fortman and S. P. Nolan, Chem. Soc. Rev., 2011, 40, 5151.

4510 D. Ortiz, M. Blug, X.-F. Le Goff, P. Le Floch, N. Mézailles and P. Maître, Organometallics, 2012, 31, 5975; R. J. Lundgren and M Stradiotto, Chem.- Eur. J., 2012, 18, 9758; S. Doherty, J. G. Knight, N. A. B. Ward, D. M. Bittner, C. Wills, W. McFarlane, W. Clegg and R. W. Harrington, Organometallics, 2013, 32, 1773.

5011 X. Shen, G. O. Jones, D. A. Watson, B. Bhayana and S. L. Buchwald, J. Am. Chem. Soc., 2010, 132, 11278.

12 O. Baudoin, Eur. J. Org. Chem., 2005, 4223, and references therein; M. Genov, A. Almorin and P. Espinet, Chem.- Eur. J., 2006, 12, 9346; Y. Uozumi, Y. Matsuura, T. Arakawa and Y. M. A. Yamada, Angew. Chem. Int. Ed., 2009, 48, 2708; T. Yamamoto, Y. Akai, Y.-U. Nagata and M. Suginome, Angew. Chem. Int. Ed., 2011, 50, 8844; T. Kamei, A. H. Sato and T. Iwasawa, Tetrahedron Lett., 2011, 52, 2638; X. Urbaneja, A. Mercier, C. Besnard and E. P. Kündig, Chem. Commun., 2011, 47, 3739; A. Ros, B. Estepa, A. Bermejo, E. Alvarez, R. Fernandez and J. M. Lassaletta, J. Org. Chem., 2012, 77, 4740; W. Wu, S. Wang, Y. Zhou, Y. He, Y. Zhuang, L. Li, P. Wan, L. Wang, Z. Zhou and L. Qiu, Adv. Synth. Catal., 2012, 354, 2395; A. Balanta Castillo, B. F. Perandones, E. Zangrando, S. Gladiali, C. Godard and C. Claver, J. Organomet. Chem., 2013, 743, 31.

6513 A. N. Cammidge and K. V. L. Crepy, Chem. Commun., 2000, 1723; J. Yin and S. L. Buchwald, J. Am. Chem. Soc., 2000, 122, 12051.

14 W. Tang, N. D. Patel, G. Xu, X. Xu, J. Savoie, S. Ma, M.-H. Hao, S. Keshipeddy, A. G. Capacci, X. Wei, Y. Zhang, J. J. Gao, W. Li, S. Rodriguez, B. Z. Lu, N. K. Yee and C. H. Senanayake, Org. Lett., $2012, \mathbf{1 4}, 2258$
15 NHC ligands in asymmetric Suzuki-Miyaura: G. Shigeng, J. Tang, D. Zhang, Q. Wang, Z. Chen and L. Weng, J. Organomet. Chem., 2012, 700, 223; L. Wu, A. Salvador, A. Ou, M. W. Shi, B. W. Skelton and R. Dorta, Synlett, 2013, 24, 1215.

7516 S. Gibson, D. F. Foster, G. R. Eastham, R. P. Tooze and D. J. ColeHamilton, Chem. Commun., 2001, 779; T. Yamamoto, T. Ohta and Y. Ito, Org. Lett., 2005, 7, 4153; K. Suzuki, T. Arao, S. Ishii, Y. Madea, K. Kondo and T. Aoyama, Tetrahedron Lett., 2006, 47, 5789; C. Qin, H. Wu, J. Cheng, X. Chen, M. Liu, W. Zhang, W. Su and J. Ding, J. $80 \quad$ Org. Chem., 2007, 72, 4102; S. Lin and X. Lu, J. Org. Chem., 2007, 72, 9757; P. He, Y. Lu, C.-G. Dong and Q.-S. Hu, Org. Lett., 2007, 9, 343; M. Kuriyama, R. Shimazawa and R. Shirai, J. Org. Chem., 2008, 73, 1597 .

17 A. Novodomskà, M. Dudičovà, F. R. Leroux and F. Colobert, Tetrahedron: Asymmetry, 2007, 18, 1628.

18 Y. Suzuma, S. Hayashi, T. Yamamoto, Y. Oe, T. Ohta and Y. Ito, Tetrahedron: Asymmetry, 2009, 20, 2751.

19 R. Zhang, Q. Xu, X. Zhang, T. Zhang and M. Shi, Tetrahedron: Asymmetry, 2010, 21, 1928

9020 F. E. Hahn, L. Wittenbecher, R. Boese and D. Bläser, Chem. Eur. J., 1999, 5, 1931; O. Buisine, G. Berthon-Gelloz, J.-F. Briere, S. Sterin, G. Mignani, P. Branlard, B. Tinant, J.-P. Declercq and I. E. Marko, Chem. Commun., 2005, 3856; C. J. O'Brien, E. A. B. Kantchev, G. A. Chass, N. Hadei, A. C. Hopkinson, M. G. Organ, D. H. Setiadi, T.-H. Tang and D.-C. Fang, Tetrahedron, 2005, 61, 9723.

21 F. E. Hahn, M. C. Jahnke and T. Pape, Organometallics, 2006, 25, 5927.

22 N. Tsoureas, A. A. Danopoulos, A. A. D. Tulloch and M. E. Light, Organometallics, 2003, 22, 4750; H. M. Lee, P. L. Chiu and J. Y. Zeng, Inorg. Chim. Acta, 2004, 357, 4313.

23 O. Navarro, H. Kaur, P. Mahjoor and S. P. Nolan, J. Org. Chem., 2004, 69, 3173 ; O. Navarro, N. Marion, Y. Oonishi, R. A. Kelly and S. P. Nolan, J. Org. Chem., 2006, 71, 685; S. Berardi, M. Carraro, M. Iglesias, A. Sartorel, G. Scorrano, M. Albrecht and M. Bonchio, Chem. Eur. J., 2010, 16, 10662.

24 F. Schmidt, R. T. Stemmler, J. Rudolph and C. Bolm, Chem. Soc. Rev., 2006, 35, 454.

25 M. Sakai, M. Ueda and N. Miyaura, Angew. Chem. Int. Ed., 1998, 37, 3279.

11026 H.-F. Duan, J.-H. Xie, W.-J. Shi, Q. Zhang and Q.-L. Zhou, Org. Lett., 2006, 8, 1479; T. Nishimura, H. Kumamoto, M. Nagaosa and T. Hayashi, Chem. Commun., 2009, 5713; S. Morikawa, K. Michigami and H. Amii, Org. Lett., 2010, 12, 2520.

27 L. Routaboul, S. Vincendeau, J.-C. Daran and E. Manoury, Tetrahedron: Asymmetry, 2005, 16, 2685; N. Mateus, L. Routaboul, J.-C. Daran and E. Manoury, J. Organomet. Chem., 2006, 691, 2297.

28 A. Altomare, M. C. Burla, M. Camalli, G. L. Cascarano, C. Giacovazzo, A. Guagliardi, A. G. G. Moliterni, G. Polidori and R. Spagna, J. Appl. Cryst., 1999, 32, 115.

12029 G. M. Sheldrick, Acta Cryst. A, 2008, 64, 112

30 A. L. Spek, J. Appl. Cryst., 2003, 36, 7.

31 H. D. Flack, Acta Cryst. A, 1983, 39, 876

32 L. J. Farrugia, J. Appl. Cryst., 1997, 30, 565; M. N. Burnett and C. K. Johnson, ORTEPIII. Report ORNL-6895, Oak Ridge National 125 Laboratory, Tennessee, USA, 1996 